\title{
Verde, blanco y encarnado: los retratos de Ángela Peralta durante el Segundo Imperio Mexicano
}

\section{Green, White, and Flesh-Color: the Portraits of Angela Peralta during the Second Mexican Empire}

Artículo recibido el 7 de junio de 2019; devuelto para revisión el 28 de enero de 2020; aceptado el II de mayo de 2020; https://doi.org/IO.2220I/iie.I8703062e.2020.117.2726

Gustavo Amézaga Heiras Universidad Nacional Autónoma de México, Facultad de Filosofía y Letras, fotografiasdelsigloxix@gmail.com, https://orcid. org/oooo-0003-IOI8-2584

Líneas de investigación Arte moderno; fotografía del siglo XIX; fotógrafos y estudios fotográficos del siglo xIx; fotografía y pintura.

Publicación más relevante De tu piel espejo. Un panorama del retrato en México, I860-19Io (México: Museo del Estanquillo), 2019.

Resumen En noviembre de 1865, la soprano Ángela Peralta regresó a su patria para presentarse ante el público de la capital y de otros departamentos del Imperio Mexicano. Las crónicas periodísticas reseñaron su llegada y recepción como un hecho sin igual. Este artículo aborda los usos y la circulación de los retratos de la artista en el contexto de la transición política del Imperio Mexicano a la República Restaurada, a partir de una investigación basada en la consulta de bibliohemerografía, colecciones particulares, archivos y otras fuentes primarias. El regreso de Ángela Peralta a México y la demanda de sus retratos manifestaron la proyección en el imaginario sobre su figura de una representación de la nación mexicana.

Palabras clave México; fotografía; retrato; siglo xIx; nacionalismo; identidad; Ángela Peralta; carte-de-visite; impresos; ópera; soprano; Segundo Imperio; República Restaurada.

Abstract Soprano Ángela Peralta returned to her country of origin November 1865 , to perform before audiences in the capital and other cities of Maximilian's Mexican Empire. Reports chronicle that all of her performances were greeted with unprecedented enthusiasm and were a spectacular success. This article draws on research in bibliographic and hemerographic sources, private collections, archives and other primary 
sources, in order to address the subsequent circulation of portraits of the artist and their utilization in the context of the political transition from the Mexican Empire to the Restored Republic. Ángela Peralta's return to Mexico and the demand for her portraits reveal the projection in the imaginary of her figure as a representation of the Mexican nation.

Keywords Mexico; photography; picture; 19th century; identity; Ángela Peralta; visiting cards; opera; soprano; Second Empire; Restored Republic. 


\author{
GUSTAVO AMÉZAGA HEIRAS
}

FACULTAD DE FILOSOFÍA Y LETRAS, UNAM

\title{
Verde, blanco y encarnado: los retratos de Ángela Peralta durante el Segundo Imperio Mexicano
}

Para el maestro Fausto Ramirez Rojas

\section{Estrella negra}

$\mathrm{D}$ el éxito estruendoso a la adversidad y desgracia, así puede resumirse la vida de la soprano Ángela Peralta. Según un testimonio de Justo Sierra, la cantante mexicana le confió que, una "estrella negra" la había acompañado durante toda su vida, ${ }^{\mathrm{I}}$ signo inequívoco de una existencia llena de penurias y desgracias, en contraste con una carrera de grandes logros y éxitos. En pleno Segundo Imperio (I864-I867), la imagen de la Peralta tuvo un culto sin precedente para una figura pública que no fuera un gobernante, político o militar. El retorno triunfal de la joven soprano venida de Europa, a finales de 1865 , a poco más de un año después de haberse establecido el imperio de Maximiliano en México, coincidió con la efervescencia de las fotografías en formato carte-de-visite; ${ }^{2}$ mismas que, al mediar la década de I860, habían cobrado una moda febril entre las clases medias y altas de la sociedad

I. Justo Sierra, Obras completas XIV. Epistolario y otros papeles privados (Ciudad de México: Universidad Nacional Autónoma de México, 199I), 68.

2. Las carte-de-visite fueron fotografías en papel montadas en un soporte de cartón que medían alrededor de $6.3 \times 10.2$ centímetros. 
mexicana. La gran circulación de los retratos de los emperadores extranjeros había impulsado tal fenómeno. ${ }^{3}$

Durante los años del breve imperio, la efigie de Ángela Peralta en formato carte-de-visite se multiplicó en una buena cantidad de fotografías, dando a conocer a la cantante y, ayudando a acrecentar su reputación. Su talento, así como la gran circulación de su imagen la consolidan como la primera personalidad mexicana en tener un amplio repertorio de retratos en dicho formato.

Sin contar la gran demanda y comercialización que en I864 tuvieron las fotografías de los emperadores extranjeros Maximiliano y Carlota en México, se puede considerar que antes de 1865 sólo circularon ampliamente los retratos de dos figuras públicas: los del presidente Miguel Miramón y la del militar texano Ignacio Zaragoza, ${ }^{4}$ ello antes del regreso de Ángela Peralta a su país.

Por medio de la pintura, la litografía y la fotografía, la figura del célebre general Miguel Miramón fue popular antes y después de su breve presidencia. El 7 de enero de I860, después de varias campañas militares en diversos estados del interior de la República, el joven presidente regresó a la Ciudad de México, por lo cual se ofreció un Te Deum en la Colegiata de Guadalupe y se realizaron otras celebraciones en la capital. Aquel día, algunas casas y edificios públicos se adornaron e iluminaron especialmente por su retorno, destacando el edificio de la Diputación en donde se colgó, entre los dos balcones principales de la fachada, el retrato al óleo del presidente, obra del pintor Jesús Corral. ${ }^{5}$ En ese mes se comercializó una partitura llamada "Los triunfos de Miramón", schotis para piano compuesto por dońa Manuela del Castillo, e ilustrada en la portada con la efigie del "excelentísimo señor presidente". ${ }^{6}$ El editor Juan N. del Valle le dedicó su guía El viajero en México donde además se incluyó su

3. Arturo Aguilar Ochoa, La fotografía durante el imperio de Maximiliano (Ciudad de México: Universidad Nacional Autónoma de México-Instituto de Investigaciones Estéticas, 1996).

4. En décadas anteriores la figura del presidente Antonio López de Santa Anna tuvo un culto importante por medio de grabados y litografías y no con base en reproducciones fotográficas. Mariana Rubio de los Santos plantea la variedad de retratos litográficos y en otros soportes que se realizaron a lo largo de los gobiernos de Antonio López de Santa Anna. Mariana Rubio de los Santos, "Retratos de luz, mercurio y plata: dos daguerrotipos del Museo Franz Mayer", tesis de maestría (Ciudad de México: Universidad Nacional Autónoma de México-Facultad de Filosofía y Letras, 2016), 29-46.

5. "Entrada del general presidente en México", La Sociedad, Ciudad de México, 8 de enero de I860, 3. En la transcripción de citas hemerográficas se respetaron los estilos tipográficos y la ortografía original de las notas.

6. "Los triunfos de Miramón", Diario de Avisos, Ciudad de México, 26 de enero de i860, 3. 
retrato. ${ }^{7}$ Posterior a su fusilamiento en el Cerro de las Campana, junto al emperador Maximiliano y el general Tomás Mejía en I867, su retrato sería altamente reproducido en formato carte-de-visite, en muchos fotomontajes y composiciones luctuosas sobre el trágico final del Segundo Imperio.

En el caso del joven general Ignacio Zaragoza, tras su gran triunfo militar en la batalla de Puebla el 5 de mayo de I862, su efigie no se comercializó en fotografías carte-de-visite ni tampoco al acontecer su muerte ese mismo año de I862; sin embargo, su imagen fue popularizada por medio de la litografía, técnica utilizada para tirajes mayores previamente al auge de las carte-de-visi$t e$. En los diferentes acervos que se consultaron no hay registro de los retratos fotográficos de Zaragoza fechados antes de 1867, como tampoco se encontraron referencias hemerográficas de que se hubieran vendido. Su imagen se promovió mediante la fotografía hasta después de caído el imperio, tras el triunfo de la República Restaurada; fue sólo entonces que la imagen de Zaragoza se integró a la iconografía y martirologio liberal.

En este contexto, a excepción del fenómeno social y comercial que representaron los retratos de los emperadores en I864, se confirma que los de Ángela Peralta fueron entonces las primeras carte-de-visite de una celebridad mexicana que se difundieron al año siguiente en este formato en boga.

Entre las colecciones fotográficas públicas y privadas, del siglo XIX, llama la atención la constante presencia de la soprano. ${ }^{8}$ Para los mexicanos de la segunda mitad de ese siglo fue común integrar, entre las páginas de sus álbumes, las fotografías de distinguidos políticos y gobernantes, militares connotados, miembros de la realeza, altas autoridades eclesiásticas o célebres cantantes, bailarinas y actrices, tanto mexicanos como extranjeros. Esta costumbre procuraba la ilusión de tener una cierta "familiaridad" con aquellas personalidades, cuyas vidas y logros se reseñaban en las crónicas de la prensa nacional. José Juan Tablada recordaba en sus memorias aquel viejo álbum familiar de cordobán "gaufré", que guardaba muchas fotografías de amigos y parientes, y entre ellos, el de Ángela Peralta, a quién evocó como "la diva".

Pero, ¿qué representó en particular la figura de Ángela Peralta?, ¿a qué se

7. "El viajero en México", Diario Oficial del Supremo Gobierno, Ciudad de México, 23 de mayo de I860, 2.

8. Entre las colecciones públicas podemos citar el acervo reunido por el escritor y cronista Carlos Monsiváis, entre los álbumes que reunió son frecuentes las fotografías de la cantante Ángela Peralta.

9. Juan José Tablada, La feria de la vida (Ciudad de México: Ediciones Botas, 1937), 50-51. 
debía esa altísima celebridad?, ¿cómo circularon sus imágenes? En este texto se exponen algunos testimonios y crónicas de cómo la joven cantante se convirtió, durante la intervención francesa, en un emblema de la patria para los dos sectores de los mexicanos, y cómo sus retratos resultaron ser un objeto de gran popularidad, a partir de los años del Segundo Imperio mexicano.

\section{Un fulgurante inicio}

Ángela Peralta Castera nació en la Ciudad de México el 6 de julio de I845, según Agustín F. Cuenca, biógrafo contemporáneo de la cantante, provenía de una familia de origen humilde. ${ }^{\text {10 }}$ Poco se sabe de su niñez y adolescencia. Ignacio Manuel Altamirano, al referirse a la situación de muchas mujeres de la época, señaló que estaban destinadas a ser "esclava[s] de la miseria, del ocio y la ignorancia"." Ángela Peralta fue una mujer a la que, por su vocación e instrucción artística, se le había permitido liberarse de esa educación "viciada aquí por las antiguas costumbres: que se formaba desde su infancia entre el fraile que la hacía temblar ante el diablo, y la esclavitud doméstica, que la encerraba en la estrechez de una vida conventual y mezquina". ${ }^{\text {I2 }}$

Cuando la pequeña Ángela dio muestras de su talento vocal empezó a recibir sus primeras lecciones de solfeo. Con tan sólo ocho años de edad, en I854 fue presentada ante la célebre primadona Henriette Sontag, que se encontraba en la Ciudad de México, y a quien le habían llegado noticias de que una nińa prodigio la imitaba. El encuentro se dio en la casa en que se hospedaba la diva $;^{13}$ ahí la pequeña interpretó algunas notas y escalas que impresionaron a la soprano alemana. Según Agustín F. Cuenca, la Sontag le auguró: "Si tu padre te llevase a Italia, serías una de las más grandes cantantes de Europa." ${ }^{14}$

Io. Agustín F. Cuenca, Ángela Peralta de Castera. Rasgos biográficos (Ciudad de México: Valle Hermanos Impresores, I873), II.

II Ignacio Manuel Altamirano, "Discurso", El Siglo Diez y Nueve, Ciudad de México, 4 de abril de 1870,3 .

I2. Altamirano, "Discurso".

I3. Henriette Sontag, condesa de Rossi, se hospedó en una residencia "ricamente amueblada" en la calle de Corpus Christi, véase "Los artistas de la ópera”, El Universal, Ciudad de México, I5 de abril de $1854,3$.

I4. Cuenca, Ángela Peralta de Castera, II. 
Ángela estudió solfeo con el maestro Luis Barragán, también canto y piano con el maestro Agustín Balderas. ${ }^{15}$ Con la educación que había logrado a sus I5 años de edad, el I8 de julio de i860, debutó en el Gran Teatro Nacional en una función de beneficio de Il Trovatore, en el papel de Leonor, una de las protagonistas de la ópera de Verdi. Su éxito fue tan aclamado, que varios periódicos de la Ciudad de México le dedicaron extensas notas a la debutante por su interpretación, destacando que "todos los artistas fueron muy aplaudidos. Las Sritas. Peralta y González repetidamente llamadas al palco escénico, recibieron ramilletes y coronas". ${ }^{16}$ Muy al estilo de la época, los seguidores de la Peralta dejaron caer desde la galería ramilletes y volantes con poemas impresos, dedicados a la cantante.

A principios de 186I, Ángela partió a Europa acompañada de su padre y de su maestro Agustín Balderas, con la idea de perfeccionar sus estudios de composición y canto en Roma y Milán; con la empresa nada fácil de desarrollar una carrera como intérprete en el Viejo continente. Cómo pudieron sufragar este viaje y la estancia en Europa no queda claro, existen pocos testimonios al respecto; su hermano Manuel Peralta Castera afirmó que lo pagaron con su propio peculio y mil pesos que aportó el señor Santiago de la Vega. ${ }^{17}$

Tras una estancia en Cádiz, España, reseñada por la prensa capitalina, ${ }^{18}$ la joven cantante debutó en los escenarios italianos contando apenas con 16 años, en el Teatro Carcano de Milán; según la prensa mexicana con "una concurrencia tan numerosísima, pues ni de pie se cabía en el teatro"; se presentaría en el escenario del teatro de Santa Radegunda y en la Scala de

I5. Manuel Peralta Castera, "Ángela Peralta”, Revista Artística, Ciudad de México (septiembre de I92I): 95 .

I6. "Función lírica de antenoche", Diario Oficial del Supremo Gobierno, Ciudad de México, 21 de julio de $1860,3$.

17. Peralta Castera, "Ángela Peralta", 95. Sobre los rumores de que el gobierno la había apoyado económicamente, su hermano aclaró en este mismo artículo: "varias veces se ha dicho que el gobierno pensionó a Ángela Peralta para que estudiase en Italia, y mal podía pensionar el Gobierno en enero de I86I, cuando hacía sólo un mes que había tomado la capital, lo cual aconteció la noche del 25 de diciembre de I860, y el que asiente lo contrario será porque desconoce la historia patria."

I8. Sobre la estancia en Cádiz se puede ver "La Srita. Ángela Peralta” y "La señorita Peralta”, ambas noticias son reproducciones del periódico gaditano El Movimiento, en donde la llaman "el ruiseñor mexicano".

19. "La señorita Ángela Peralta”, El Siglo Diez y Nueve, Ciudad de México, 7 de junio de I862, 4 . 
Milán, desempeñando, en este último con gran éxito, el rondó final de Lucía de Lammermoor, pieza de lucimiento para sopranos de coloratura, y papel reservado para cantantes muy capaces.

De este periodo inicial en Milán, Italia, existen al menos tres fotografías de Ángela Peralta, tomadas en esa ciudad por Giovanni Battista Ganzini, probablemente entre I864 y I865, cuando su estudio se ubicaba en la Via dell' Unione, 4. En una de esas imágenes, la soprano aparece tocando el piano, acompañada por un flautista, ambos de perfil; la representación en el estudio se complementa con la presencia del maestro Agustín Balderas quien, sosteniendo un sombrero de copa y posando a manera "de llegar" a la escena, parece aprobar lo que escucha de sus alumnos (fig. I). En los otros dos retratos individuales, Ángela posa en personaje, se muestra gesticulando ante la cámara; probablemente, se trate de la representación de Lucía Ashton, del drama trágico Lucía de Lammermoor, ya que porta el característico vestido blanco de la protagonista; las poses pueden aludir a los desvaríos de la dama que enloquece de amor (figs. 2a y b). Estos retratos debieron realizarse para que circularan y se conociera a la novel cantante, entre un sector de empresarios, compositores, críticos y colegas, y con seguridad estuvieron a la venta a todo el público italiano, fervientes seguidores del arte de la ópera. ${ }^{20}$

Ángela Peralta inició una primera gira de presentaciones operísticas por múltiples ciudades de Italia, España, Portugal y Egipto, inclusive, cantó en "salones aristocráticos" de París. ${ }^{21}$ Las crónicas de sus éxitos en Europa se publicaron en los periódicos mexicanos, tanto de talante conservador, como liberal.

Durante la estancia de la cantante en Europa, el proyecto republicano en México encabezado por el presidente Benito Juárez enfrentaba la intervención francesa de Napoleón III de Francia, que no sólo costó la vida de miles de hombres de ambos bandos, ${ }^{22}$ sino que implicó la imposición de un empe-

20. Desde principios de la década de i860 los fotógrafos de las grandes capitales ofrecieron galerías de celebridades a la venta, algunos de ellos inclusive por medio de catálogos.

21. "Anjela Peralta", El Pájaro Verde, México, I8 de noviembre de I865, 2. El diario conservador reprodujo información de los periódicos Le Monde Artistique de París, Diritto de Turín, Democrático de Forlì y de Discussione.

22. No hay registro oficial del número de muertos durante la guerra de Intervención francesa y el Segundo Imperio. Basilio Pérez Gallardo calculó en 1875, en un folleto titulado Martirologio de los defensores de la Independencia de México, que, en un total de I,O2O acciones de guerra, los imperialistas sufrieron I2,209 bajas, y los republicanos 73,037, entre muertos, heridos y prisioneros. Como sea, José María Vigil advierte que estas cifras son más bien aproximadas; 
I. Giovanni Battista Ganzini, Ángela

Peralta, Agustín Balderas y otro personaje no identificado, $c a$. 1865 , albúmina, $6.3 \times 10.2 \mathrm{~cm}$. Colección particular.

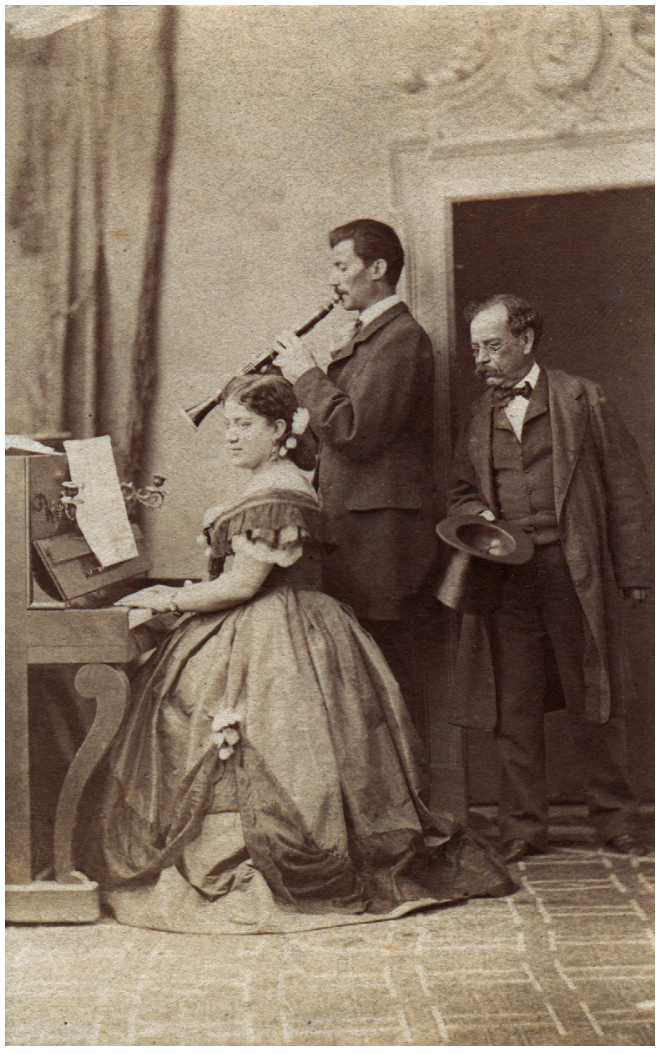

rador extranjero dispuesto por el monarca francés: Maximiliano de Habsburgo, quien gobernó el imperio mexicano tan sólo tres años, de I864 a 1867. Durante su estadía en Europa, Ángela Peralta conocía la situación por la que atravesaba la nación mexicana. En 1864, el escritor José González de la Torre refirió una dedicatoria que escribió la cantante en una fotografía, en la que se reflejaba su sentir: "Nuestra compatriota está en Italia; pero su corazón está aquí. Ella sufre, porque se mira ausente de su patria, y al escribir una dedicatoria en el retrato que regalaba a un amigo, dejó hablar a su corazón y exhaló un gemido

José María Vigil, México a través de los siglos, vol. V (Ciudad de México y Barcelona: Ballescá y Comp./Espasa y Comp., I884), 86I. A su vez, Jesús León Toral calcula en 20,000 las bajas entre las tropas extranjeras (Jesús de León Toral, Historia militar. La Intervención francesa en México [Ciudad de México: Congreso Nacional de Historia para el Estudio de la Guerra de Intervención, 1962]), 299-300. Agradezco a Patricia Galeana estas referencias. 
de angustia, un grito de amor patrio, sentido y tierno como no lo habría sido el fino pensamiento de un literato." ${ }_{23}$

En I865, Ángela Peralta de tan sólo 20 años, fue contratada para volver a México por el empresario Annibale Biacchi, ${ }^{24}$ quien anunció su regreso de la siguiente forma: "Esta joven que ha llevado con gloria el nombre de México por toda Europa y hasta en los apartados climas de África, ha desechado partidos brillantes por volver, aunque sea por poco tiempo, a visitar su adorada patria, a dar un abrazo a sus paisanos y amigos." ${ }^{25} \mathrm{El}$ inicio de la mitificación de su figura pública fue una construcción de una nación que se debatía entre dos proyectos abismalmente diferentes.

\section{El recibimiento triunfal}

Pese a la inestabilidad política, a los incesantes cambios de gobiernos, aunado a las invasiones extranjeras, a lo largo del siglo xIx mexicano se desarrolló una intensa vida cultural. El género lírico sirvió como articulador de intenciones de grupos que, si bien, con ideas políticas a veces antagónicas, se desenvolvieron en una especie de proyecto que a la distancia forjó identidad, cultura, y funcionó como instrumento "civilizador". ${ }^{26}$

Para comprender el contexto del retorno de la soprano a su país, hay que señalar que hacia finales de 1865 , en Francia se debatía la inminente retirada de las tropas y los ejércitos intervencionistas de Napoleón III, lo que auguraba el desmoronamiento del Segundo Imperio mexicano. En el puerto de Veracruz la joven cantante coincidió con la emperatriz que partía a una gira por la

23. "La señorita Peralta", El Pájaro Verde, Ciudad de México, 9 de marzo de i864, 3.

24. Mucho se ha referido en el favoritismo de Maximiliano hacia Biacchi, aunque poco se ha podido comprobar. El Archivo General de la Nación resguarda una carta del 2 de octubre de I865 en la que el empresario italiano solicitó una audiencia con su majestad, la cual le fue negada; el secretario del gabinete Imperial le pidió por escrito su comunicación al emperador. Fondo Segundo Imperio, caja 7, exp. 004. Agradezco a la investigadora Áurea Maya la referencia de este documento.

25. "Gran Teatro Imperial. Ópera italiana. Prospecto", La Sociedad, Ciudad de México, i6 de agosto de $1865,3$.

26. Áurea Maya, "La ópera en el siglo XIx en México: resonancias silenciosas de un proyecto cultural de nación (I824-1867)", en Los papeles de Euterpe. La música en la Ciudad de México desde la historia cultural. Siglo XIX (Ciudad de México: Instituto de Investigaciones Dr. José María Luis Mora, 2014), 229-330. 

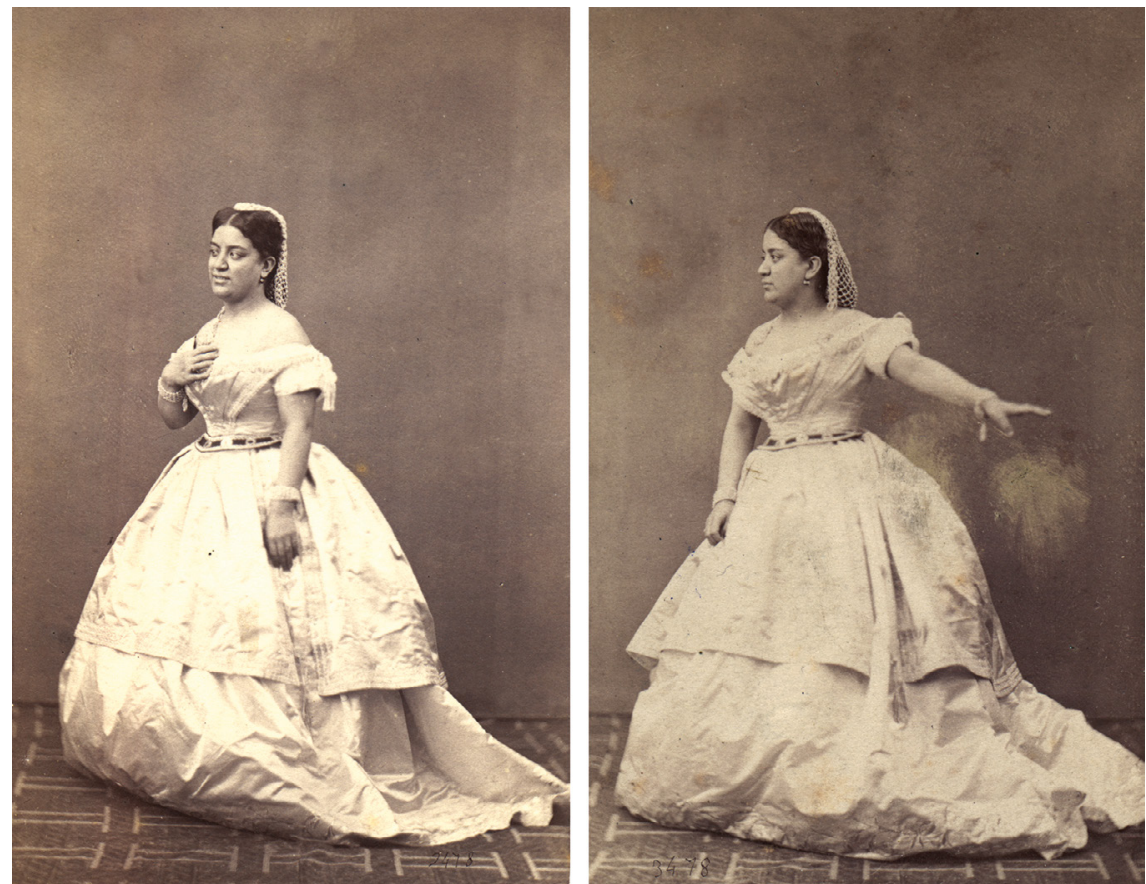

$2 a$ y b) Giovanni Battista Ganzini, Ángela Peralta como Lucía de Lammermoor, ca. 1865, albúminas, $6.3 \times 10.2 \mathrm{~cm}$. Colección particular.

península de Yucatán; la soprano cantó en una tertulia ante Carlota, ${ }^{27}$ al igual que lo haría después en un concierto frente al emperador Maximiliano en Palacio, en donde interpretó "Le Pardon de Ploërmel" de Meyerbeer. ${ }^{28}$

El regreso de Ángela Peralta constituyó un suceso excepcional; para el arribo de la cantante a la Ciudad de México, programado para el 20 de noviembre de 1865 , procedente del puerto de Veracruz, se planeó un primer punto de reunión en el pueblo de Iztapalapa, donde se daría el encuentro con su madre,

27. "La emperatriz en Veracruz", Diario del Imperio, México, I4 de diciembre de I865, 2. La emperatriz la mencionó brevemente en su correspondencia al emperador, véase la carta del I6 de noviembre de 1865 de Carlota a Maximiliano escrita desde Veracruz, Konrad Ratz, ed., Correspondencia inédita entre Maximiliano y Carlota (Ciudad de México: Fondo de Cultura Económica, 2003), 233.

28. Carta de Maximiliano a Carlota, 9 de diciembre de 1865 , en Correspondencia inédita. No se localizaron crónicas o descripciones en la prensa de la actuación de la joven soprano ante el emperador. 
hermanos y seguidores. Días antes, los entusiastas alumnos de la Academia de San Carlos, identificados con la joven intérprete, fijaron "carteles incendiarios" que pegaron en las esquinas de las calles, en los que convocaban al público a salir a recibir a la Peralta en la Garita de San Antonio Abad. ${ }^{29}$ Aquel día, no había caballo, calesa, ni vehículos en alquiler en la ciudad, todos querían recibir a la célebre soprano; tan sólo los artistas de la ópera iban en 40 carruajes, además de otros coristas, músicos y miembros de la orquesta. ${ }^{30}$ Manuel Peralta Castera evocaría, años después, detalles de aquella entrada triunfal de su hermana y del emotivo reencuentro con su madre:

Todo el mundo quería salir al camino a encontrar a la compatriota y saludarla en primero [...] Al encontrarnos con la diligencia en que venía "el ruiseńor mexicano", el entusiasmo que ardía en todos llegó al colmo. Vivas, gritos, etcétera. Unidas carroza y diligencia, madre e hija se tiraron a tierra y se echaron en brazos; entonces, aquellas aclamaciones, aquel entusiasmo enmudeció y los caballeros se descubrieron. Aquello fue verdaderamente imponente..$^{3 \mathrm{~T}}$

En Iztacalco, se organizó la marcha de la siguiente manera: el desfile de la comitiva lo iniciaba un empleado del Teatro Imperial, ${ }^{32}$ montado a caballo; después, en una calesa abierta, tirada por cuatro caballos — seguramente decorada por festones tricolores — iba la señorita Peralta y su madre atrás, ${ }^{33}$ las seguían incontables jinetes y una verdadera multitud en carruajes y a pie, con teas y faroles encendidos. La procesión retomó el trayecto a la ciudad, haciendo paradas en diversas estaciones para recibir las manifestaciones públicas de júbilo y cariño. En la Garita de San Antonio Abad, esperaba a la cantante una multitud de admiradores y colegas; ahí se improvisó una tribuna, se leyeron versos, se pronunciaron discursos y los alumnos de la Academia de San Carlos le colocaron una corona de laureles con hojas de oro, ligadas por cintas de "los colores nacionales" ${ }^{\prime 4}$ y, acompañados todos de la banda del Batallón de Policía, se

29. "Obertura. A toda Orquesta", La Orquesta, Ciudad de México, 20 de diciembre de 1865 , I.

30. "La Srita. Anjela Peralta", El Pájaro Verde, Ciudad de México, 23 de noviembre de I865, 2.

31. Peralta Castera, "Ángela Peralta”, roo.

32. El Gran Teatro de Santa Anna inaugurado en I844, proyecto del arquitecto Lorenzo de la Hidalga, cambió sucesivamente de nombre, se llamó después Gran Teatro Vergara, Gran Teatro Imperial y por último, Gran Teatro Nacional.

33. "La Srita. Peralta", El Pájaro Verde.

34. "Anjela Peralta", El Pájaro Verde, Ciudad de México, 24 de noviembre de I865, 3. 
tocaron los acordes de las dianas y se cantó el Himno Nacional, interpretado por un pueblo "borracho de patriotismo". ${ }^{35}$ Finalmente, a las ocho de la noche, e iluminada por una "farola con los colores nacionales", ${ }^{6}$ Ángela pudo llegar con su comitiva, tras recibir a su paso aclamaciones de una infinidad de compatriotas que la acompañaron hasta la puerta del hogar de la familia Peralta Castera, en la calle de Vergara i3 (hoy Bolívar). Ángela bajó de su carruaje bañada en llanto por la emoción de aquellas manifestaciones de carińo, que la hicieron salir al balcón a presenciar el desfile que duró hasta las once de la noche entre todo tipo de aclamaciones rebosadas de entusiasmo "lírico y patriótico". ${ }^{37}$ El periodista e historiador, Armando de Maria y Campos, consideró que tan entusiasta recibimiento fue una demostración del pueblo "ganoso de vitorear libremente a México, oprimido por la administración franco imperialista y agitado por los vientos de su reconquista, proclamada por el partido liberal".$^{38}$ La realidad es que la figura de la joven cantante unió en un solo público a los mexicanos de diferentes ideologías políticas que deseaban expresarle su admiración y reconocimiento.

Una semana después, el 28 de noviembre de 1865 , en el Gran Teatro Nacional, que durante el Segundo Imperio se llamó el Gran Teatro Imperial, se escenificó la ópera La sonámbula, protagonizada por la soprano mexicana, ${ }^{39}$ ante un público que incluso llegó de otras ciudades, ex profeso para oírla cantar. ${ }^{40}$ A pesar de las agitaciones políticas de la época, los liberales republicanos, "que ardían como pira volcánica contra la osadía del sistema imperial impuesto por la fuerza extranjera", ${ }^{41}$ convivieron con los conservadores imperialistas, reuni-

35. Armando de Maria y Campos, Ángela Peralta. El ruiseñor mexicano (Ciudad de México: Ediciones Xóchitl, 1944), 65.

36. "La Srita. Peralta”, El Cronista de México, Ciudad de México, 22 de noviembre de 1865, 3.

37. "Mlle. Angela Peralta”, L’Ere Nouvelle, Ciudad de México, 22 de noviembre de I865, I.

38. De Maria y Campos, Ángela Peralta, 64.

39. "Presentación de la Srita. Peralta en la escena mexicana", La Sombra, Ciudad de México, I de diciembre de $1865,3$.

40. La maestra Carmen Lugo Hubp, por herencia familiar fue gran admiradora de Ángela Peralta, y en entrevista personal, me contó que sus bisabuelos se trasladaron desde San Luis Potosí hasta la capital del imperio para presenciar el debut de la soprano. El relato, que también fue transmitido por Carmen de manera oral en 1985 , provocó que esta historia en torno a la cantante fuera incluida en un texto escrito por Isabel Haza Peralta, sobrina nieta de la soprano, en la revista Fem, publicada en octubre-noviembre de 1985. Entrevista con la maestra Carmen Lugo Hubp, Ciudad de México, 9 de septiembre de 2016.

4I. Hernán Rosales, Amado Nervo, la Peralta y Rosas (Ciudad de México: Herrero Hermanos Sucs., 1926), 92. 
dos ambos bandos en un mismo teatro para admirar a su compatriota a la que sólo deseaban escuchar.

Cuando llegó el turno de Ángela para salir a escena, en su papel de la aldeana Amina en medio de una nube de color rosa suave — producto de un conjunto de luces de bengala hábilmente dispuestas— ${ }^{42}$ la cantante apareció vestida con los colores nacionales, tal como lo describió el periódico El Cronista de México: "la señorita Peralta se presentó graciosamente vestida, formando la enagua de su traje los colores del pabellón mexicano, verde, blanco y encarnado" ${ }^{43} \mathrm{El}$ atuendo tricolor resultó otro golpe emocional para el reencuentro con el público mexicano. En aquel momento, los espectadores rompieron en frenéticos aplausos que duraron largo tiempo; una lluvia de pajillas doradas empezó a descender de palcos y balcones; el vasto auditorio y el proscenio se inundaron de flores y de coronas para la soprano; una nube de sonetos, cuartetos y odas de todos los colores oscurecían la sala, mientras que "la orquesta tocaba el aire de triunfo de las carreras de toros, y el 'gallinero' se removía gritando, como si todos los 'monos gritones' de Yucatán lo hubiesen invadido". ${ }^{44}$ Pocos años después, un periodista, de seudónimo "Corindro", recordaría en un artículo que la cantante había personificado "a la Patria en su individualidad. El reprimido despecho republicano, bajo la férula del invasor triunfante, halló el digno objeto ante quien desahogar las emociones de su corazón. Ángela Peralta era la bandera de la República”. ${ }^{45}$

Resulta comprensible la estruendosa reacción de la audiencia. En I873 Agustín F. Cuenca definió de este modo el momento histórico por el que atravesaba la nación:

Era entonces, la noche en el cielo de nuestras libertades; era entonces el estremecimiento de muerte en el corazón de la patria; era el pabellón francés el sudario tendido sobre el sol de Dolores; era, en fin, el combate de la magestad del derecho ultrajado con la hidra devoradora de la usurpación.

42. “Opéra italien”, L'Ere Nouvelle, Ciudad de México, Io de diciembre de I865, I.

43. "La Srita. Angela Peralta", El Cronista de México, Ciudad de México, 30 de noviembre de $1865,3$.

44. "Opéra italien", L'Ere Nouvelle. El término "el aire de triunfo de las carreras de toros", se refiere a las fanfarrias o dianas que se interpretaban en las corridas de toros; el del "gallinero" al de la galería o gayola más alta del teatro, de localidades más económicas.

45. Corindro, "Triunfo de Angelita Peralta en Puebla", El Federalista, Ciudad de México, 8 de agosto de I87I, 2. 
Nuestra bandera, el talisman adorado de nuestros valientes soldados, fué saludada con un ¡viva! unánime y repetido muchas veces, como la fiel expresión de un patriotismo inmaculado y con fiebre en aquellos momentos. ${ }^{46}$

Por su parte, Armando de Maria y Campos relató que aquella noche, "era de ver aquel teatro pletórico de gente con un lujo asiático, todo el mundo con la satisfacción en el rostro, orgulloso de tener una compatriota de la talla de Ángela”. ${ }^{47}$ Concluido el espectáculo, la concurrencia pidió que la soprano regresara a escena para tributarle una larga ovación. El recuerdo de esa memorable función perduraría por largo tiempo en quienes asistieron. Entre los muchos poemas impresos en papeles multicolores, que le arrojaron a la Peralta, destaca uno escrito por el editor y fotógrafo Juan Abadiano, ${ }^{48}$ en el que se hace referencia a la patria intervenida y herida:

En vuelta en su dolor hondo y creciente,

Entre sombras de muerte, horror y duelo,

Tu patria hermosa, la del claro cielo,

Un grito lanza de entusiasmo ardiente.

La cabeza levanta refulgente,

Y olvidando su amargo desconsuelo,

Con las flores más puras de su suelo

Corona, altiva, tu inspirada frente.

¡Salve mil veces, ruiseñor canoro!

Ven a tu patria, ven, ángel querido,

Y calma con tu voz su triste lloro. ${ }^{49}$

Sin embargo, no todos los comentarios fueron positivos para Ángela Peralta, un cronista anónimo del periódico L'Ere Nouvelle publicó una extensa nota, el Io de diciembre de I866, donde cuestionaba mordazmente los méritos y trayectoria de la joven soprano mexicana, criticó la atmósfera demasiado benevolente por parte del público nacional, así como sus dotes para el canto, calificando el deslumbrante triunfo como "discernido antes de la victoria [...] lo que debía

46. Cuenca, Ángela Peralta de Castera, 33.

47. De Maria y Campos, Ángela Peralta, 67.

48. Juan Abadiano tuvo dos establecimientos fotográficos en la calle de Espíritu Santo núm. i y en la i ${ }^{a}$ de Plateros núm. 5 .

49. "La Srita. Ángela Peralta”, El Cronista. 
intimidar a la crítica e incitarla a la desconfianza"..$^{\circ}$ La defensa no se hizo esperar. El escritor Lorenzo Elízaga publicó en el diario Noticioso en Veracruz, en diciembre de 1865 , un apasionado artículo en el que señaló al "señor X, digno cronista de tal periódico", como "el odioso sistema" de L'Ere Nouvelle, de "denigrar todo lo que es mexicano", y cuestionó a "Monsieur X", los servicios que prestaba al periódico. Finalmente, reprodujo dos elogiosos textos sobre la Peralta, publicados en Bolonia y París. ${ }^{\text {st }}$

El 29 de enero de 1866 , en el Teatro Imperial, se realizó una función de beneficio $^{52}$ de la cantante. La aparición de la soprano en el escenario se dio en medio de una "luz eléctrica con que en aquel instante se iluminó la escena", en esa ocasión ella portaba "un traje que ostentaba los colores de la bandera nacional". ${ }^{33}$ De la soprano, existe una fotografía de Francisco Casanova, tomada años después, que pudiera tratarse del registro de Ángela Peralta como la protagonista de La sonámbula; en ella, la cantante posó de frente recogiendo flores, portando un delantal blanco y una pañoleta sobre su cabeza; al parecer ostenta la vestimenta tricolor que reseñan las crónicas; seguramente, Ángela Peralta quiso dejar testimonio de aquel atuendo con el que se consagró ante el público mexicano (fig. 3).

Para los seguidores de su edad y para los estudiantes que la tomaron como un modelo de esperanza y triunfo, Ángela Peralta se expresó implacable en el tema de patriotismo; según relató Justo Sierra acerca de esa misma función, ella fue musa e inspiración para la generación de los jóvenes liberales:

Nada teníamos que celebrar entonces, porque el desastre había sido tal para la santa causa de la República, que los antiguos triunfos parecían soles muertos; después, había habido tanto luto, tanta derrota, tanta sangre, que parecía que del 5 de Mayo a aquella fecha, un siglo había transcurrido. Y como la juventud necesita de fiestas, todos encontramos que la única fiesta lícita, que el único regocijo que nos era

50. “Opéra italien”, L'Ere Nouvelle, Ciudad de México, Io de diciembre de I865, I.

51. Lorenzo Elízaga, Ensayos politicos. Colección de artículos escritos y publicados en diversos periódicos, durante la usurpación de Maximiliano (Ciudad de México: Tipografía de Juan Abadiano, I867), 58-62. La defensa de Elízaga en el Noticioso sería ampliamente reproducida y comentada por la prensa capitalina.

52. Función de teatro u ópera, cuyo producto en taquilla se le concedía a una persona, o a una institución.

53. "La Srita. Da. Ángela Peralta", El Cronista de México, Ciudad de México, 3I de enero de 1866, 2. 
3. Francisco Casanova, Ángela

Peralta, $c a$. I870, albúmina, $6.3 \times 10.2 \mathrm{~cm}$. Colección Eduardo

García Ramírez.

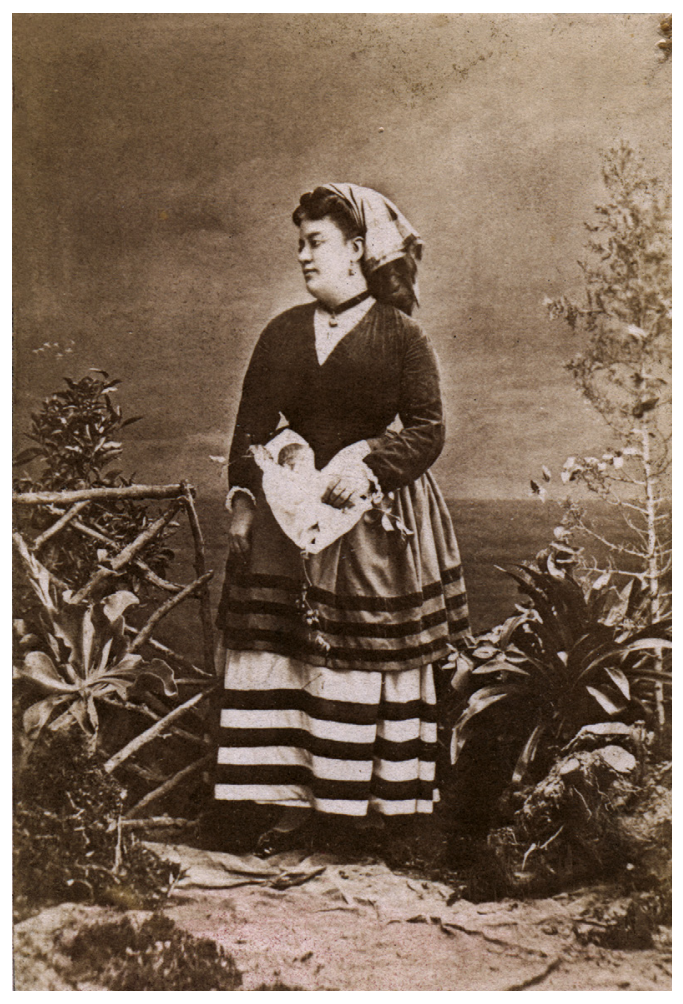

permitido, era celebrar las glorias de aquella mexicana en cuyos acentos creíamos oír o los ayes de la patria moribunda o los preludios del himno del triunfo. Ella sí esperaba, ella sí creía. Cierta noche la de su brillante [función de] beneficio, fiesta teatral y ovación verdaderamente gigantesca, no he visto otras iguales, algunos estudiantes pudimos arrancarla algunos minutos a las felicitaciones, la rodeamos, la aislamos, le hablamos conmovidos de la patria ausente, muerta quizá, dijo uno de nosotros. Muerta nunca, nos respondió, y con su voz que parecía una campana de oro, nos habló de la fe y de esperanza de tal modo, con tal acento, que salimos de allí arrebatados de entusiasmo; nos había hablado una sibila, no había duda, conocíamos el oráculo. ${ }^{54}$

54. Sierra, Obras completas, 68-69. 
En aquella misma función, la prensa local registró que la beneficiada no dedicó públicamente la función a los emperadores por encontrarse de luto la corte, tras el fallecimiento de Leopoldo I de Bélgica, padre de la emperatriz Carlota. En uno de los entreactos de la velada se leyó una carta dirigida a Ángela Peralta, firmada por el secretario de ceremonias del emperador, Pedro Celestino de Negrete quien, a nombre de Maximiliano, la nombró "cantarina de cámara", ss y le envió un obsequio, que las notas de los periódicos conservadores refirieron como un brazalete de diamantes. Agustín F. Cuenca relató que tal regalo la cantante sólo lo "pudo aceptar como artista", ${ }^{56}$ dejando entrever que no lo hubiera admitido como mujer o ciudadana. Por su parte, la crónica del periódico liberal La Orquesta, socarronamente con las siguientes estrofas, hizo referencia a la asistencia de un público diverso: "Y hubo vivas, y reclamos/ Coronas, flores y aromas/Y alegóricas palomas/ Y ramos de todos [los] ramos". ${ }^{57}$ Sin embargo, el gesto de la soprano de aceptar el nombramiento imperial, le costó la burla de liberales como Ignacio Manuel Altamirano quien —según Hernán Rosales, biógrafo de la Peralta - afirmó en un periódico del interior del país que "toda la frescura de los laureles que Ángela Peralta había traído de Europa, se marchitaba tristemente, vergonzosamente, ante la aceptación de ese nombramiento de una corte bufa y oprobiosa".$^{58}$ Años más tarde Altamirano escribiría sobre su relación con la cantante, convirtiéndose después en su amigo, promotor y uno de sus principales defensores. ${ }^{99}$ Desgraciadamente no se localizó

55. "Beneficio de la Srita. Peralta", La Sociedad, Ciudad de México, 3I de enero de 1866, 3 y "La señorita Peralta", El Mexicano, Ciudad de México, I de febrero de I866, 8.

56. Cuenca, Ángela Peralta de Castera, 33.

57. La nota sobre la función de beneficio de la cantante estuvo acompañada de una caricatura de Constantino Escalante, en la que se aprecia una fila del público que entra al teatro, entre ellos, unos niños que portan en dos charolas pilas de coronas para arrojar a la cantante, mientras que, entre las columnas del Teatro Nacional, José Gutiérrez Estrada y, más atrás casi entre las penumbras, Antonio López de Santa Anna, observan incrédulos el espectáculo. La leyenda al pie de la imagen explica que tan sólo ellos consideraban que tenían el privilegio de "ofrecer coronas". "Triunfos", La Orquesta, Ciudad de México, 3I de enero de 1866, 2-3. Agradezco la referencia a la investigadora Helia Bonilla Reyna.

58. Rosales, Amado Nervo, la Peralta y Rosas, 95-96. Altamirano después reconocería en una carta dirigida a don Joaquín Casasús en i89i, que el compositor Melesio Morales lo habría predispuesto contra Ángela Peralta. Ignacio Manuel Altamirano, Obras completas. Epistolario (I889-1893), t. II (Ciudad de México: Consejo Nacional para la Cultura y las Artes / Tribunal Superior de Justicia del Distrito Federal, 20II), 2IO.

59. Ignacio Manuel Altamirano, "La Peralta y sus defensores", El Federalista, Ciudad de México, 24 de septiembre de 1871, 2-3. 
un documento o una nota en la prensa sobre la postura política de Ángela Peralta; las referencias fueron siempre en notas o relatos de terceras personas.

Los testimonios sobre la interpretación de su figura identificada con los ideales republicanos fueron consignados años después del triunfo del discurso liberal. En I872, el periódico La Bandera de Juárez reconocía que "el sentimiento patriótico comprimido, halló un motivo de expansión con la llegada de nuestra compatriota [...] En aquellos momentos Ángela Peralta era más que una mujer, más que una artista; era la encarnación de la patria, era el desquite de tantas lágrimas, de tanta sangre, de tanta infamia, de tanto baldón”. También se reconocía, que se le asociaba "no solo al sentimiento del arte, sino al mas vivo y mas intenso de la patria". ${ }^{60}$

Durante la gira por otros departamentos, del entonces imperio mexicano, se suscitaron brotes apasionados que la prensa llamó "demostraciones entusiastas", y que se dieron en las funciones de Los puritanos, en particular en la presentación del "dúo de las banderas". En esta ópera de Bellini, que narraba el drama amoroso entre Elvira y Arturo, en plena guerra interna en Inglaterra, se confrontaban dos puntos de vista, por un lado, el de los puritanos partidarios de Olivier Cromwell que promovían una república y la libertad; contra sus opositores realistas que apoyaban a la casa de los Estuardo. En sí misma, esta puesta en escena en esos momentos se convertía en una metáfora de la guerra civil entre los conservadores y los liberales mexicanos. El periódico La Sombra registró que la policía "había impedido ó restringido algunas de las demostraciones entusiastas" y, en un verso reproducido del diario La Realidad de Puebla, se mofaban de tal imposición: "En un duo ó en una aria/ de Traviata ó Puritanos, / No puede haber sedición/ Aunque salieran muy malos." ${ }^{61}$

Como señala el historiador Jaime Cuadriello, el teatro tuvo un papel decisivo como catalizador político y social de la vida urbana, este coliseo decimonónico se erigió como una suerte de templo civil, desde cuyos foros se presidieron múltiples y peculiares eventos de la nueva conciencia nacional. ${ }^{62}$ En ese contex-

6o. "El beneficio de Ángela Peralta”, La Bandera de Juárez, Ciudad de México, 20 de noviembre de $1872,2$.

6I. "Restricción”, La Sombra, Ciudad de México, I6 de marzo de 1866, 4. En Guanajuato, Lucio Marmolejo describiría la reacción delirante del público durante el "dúo de las banderas", interpretado por los cantantes Maffei y Capelli portando la enseña tricolor (La Sociedad, Ciudad de México, I2 de junio de I866, 2); lo mismo ocurriría en Guadalajara según el relato de Irineo Paz en su obra Algunas campañas (México: Imprenta y Litografía de Irineo Paz, vol. I, I884, 192).

62. Jaime Cuadriello, "El ámbito del teatro mexicano: de la calle a su casa", en Teatros de México (Ciudad de México: Banamex, 199I), 48. 
to, Ángela Peralta representó en pleno imperio, "la figura de la protesta" ante la dominación francesa; así la recordó Justo Sierra, evocando su regreso, por medio de estas palabras: "Y le cupo la suerte de ser un día la encarnación, si no de la República, sí de la protesta contra el extranjero que nos invadía. Tengo bien presentes aquellas sus victorias artísticas cuando volvió por primera vez de Italia, en tiempos del imperio." ${ }_{3}$

Cuando la soprano se presentó en Guadalajara, Irineo Paz describió su sentir sobre la soprano: "Nos figurábamos que en ella estaba representada la República y consagramos para ella el mas ferviente culto, en cada uno de nuestros corazones." ${ }^{64}$ El escritor y periodista tapatío le compuso un poema, que se le declamó en pleno escenario, y que decía entre sus estrofas: "Hoy las penas son impías.../ Tal vez en mejores días/ Amaremos mas tu gloria." "6s Este acontecimiento, Paz lo recordó así: "mi composición fue aplaudida con frenesí. Estábamos dominados por la ley del sable y divisábamos en el porvenir una perspectiva de libertad, ¿`cómo no habiamos de dar espansiones á nuestro aprisionado entusiasmo" ${ }^{66}$ Según su testimonio, las palabras y las arengas libertarias al pueblo y a la soprano, por poco le cuestan ir a dar a la cárcel.

La investigadora Ingrid S. Bivián propone que la figura de Ángela Peralta fue el vehículo mediante el cual la sociedad mexicana expresó algunos de sus anhelos y pesares: primero, hacer de México un país a la altura de los más civilizados y, segundo, el significado opuesto que le dieron tanto los liberales como los imperialistas a la joven soprano, encarnando el símbolo o representación de sus propios proyectos e intereses. La misma autora sostiene que el imperio, queriéndose congraciar con sus súbditos, reconoció a la joven cantante, mientras que los republicanos apoyaron a la soprano con más ahínco desde la trinchera periodística. ${ }^{67}$

La imagen de la cantante, tanto en su versión fotográfica, como litográfica, habría de multiplicarse para acompañar los poemas, los versos y los sonetos impresos en infinidad de hojas de papel de distintos colores "con un retrato de

63. Sierra, Obras completas, 68.

64. Ireneo Paz, Algunas campañas (Ciudad de México: Imprenta y Litografía de Ireneo Paz, vol. I, I884), I9I-I92.

65. Paz, Algunas campañas, I93.

66. Paz, Algunas campañas, 194.

67. Ingrid S. Bivián, "El canto del 'ruiseñor': un acercamiento a la creación del mito de Ángela Peralta (1860-1866), en Los papeles de Euterpe. La música en la Ciudad de México desde la historia cultural. Siglo XIX, 375 . 
la señorita Peralta", ${ }^{68}$ que el público mexicano de cualquier filiación política le arrojaba al patio y al proscenio de los teatros donde se presentó. Estas poesías dedicadas a la soprano, complementadas con su fotografía, se convirtieron en un impreso constante según se verá más adelante.

\section{"El álbum fotográfico"}

Como se ha señalado, la imagen y la vida de Ángela se convirtieron en un asunto de enorme popularidad: desde antes de su triunfal regreso a México, en noviembre de 1865 , circularon impresos y fotografías con la biografía de la cantatriz. Una carte-de-visite, con una nota biográfica al reverso, se empezó a comercializar en la Ciudad de México a partir de abril de ese año —-siete meses antes de su llegada - como parte de "El álbum fotográfico", que se vendió por entregas semanalmente. Dicha publicación, escrita y editada por José Tomás de Cuéllar, ${ }^{69}$ pretendía ser una "colección de retratos de todos los monarcas del mundo, de notabilidades científicas, artísticas y literarias y galería de reproducciones de los mejores cuadros que enriquecen los museos de Europa y América. Cada retrato contendrá en el reverso una ligera noticia biográfica" ${ }^{70} \mathrm{El}$ editor del álbum también afirmaba que las imágenes "de todos estos personajes están tomadas de los originales más auténticos, y muchos son reproducciones de fotografías tomadas del natural", como fue el caso del retrato de la Peralta (fig. 4), que probablemente se realizó en Italia, antes de su retorno a México. La figura de la soprano se incluyó en un conjunto de 33 personalidades, entre gobernantes y destacados protagonistas de la ciencia y el arte, tanto de tiempos pasados, o contemporáneos a ella. Aparecían las imágenes de Dante, Carlos V, Miguel de Cervantes, Juan Ruiz de Alarcón, Francisco Quevedo, Alexander von Humboldt, Giacomo Rossini, el rey Leopoldo I, Víctor Hugo, Manuel Bretón de los Herreros y Carpio, entre otros. Además de dos reproducciones de cuadros: El descendimiento de Rubens y Rafael $y$ la Fornarina de Ingres.

68. De Maria y Campos, Ángela Peralta, 72.

69. El ro de abril de I865, el escritor José Tomás de Cuéllar solicitó el registro y la propiedad literaria de "El álbum fotográfico". "Ministerio. Documentos de Gobernación", Diario del Imperio, Ciudad de México, I8 de abril de $1865,366$.

70. "El álbum fotográfico", El Cronista de México, Ciudad de México, i8 de abril de I865, 3. 
De aquel conjunto, solamente se incorporaron los retratos de seis mujeres: María Estuardo, sor Juana Inés de la Cruz, la emperatriz Eugenia, Isabel II de España, miss MacDonald y Ángela Peralta. Sin duda, la figura de la soprano mexicana era la más joven, de entre aquella galería que pretendía ambiciosamente:

Difundir la ilustración sin necesidad de sacrificio, ni estudio; hará adquirir al que lo posea conocimientos precisos de las dinastías, de los reinados, de las costumbres, de los pueblos, y del nacimiento y progreso de las ciencias y las artes, y servirá de apoyo y memorándum en el estudio y conocimiento de la historia y la geografía; y hasta las personas que desdeñan la instrucción, tendrán en este Álbum, para halagar su gusto, retratos de artistas y mujeres hermosas, seres que simpatizan con todo el mundo. ${ }^{71}$

Para la edición de esta curiosa recopilación, José Tomás de Cuéllar ${ }^{72}$ recurrió a la tecnología más moderna y práctica en su tiempo, que era la fotografía en formato carte-de-visite, que sirvió para la divulgación de las notas biográficas del álbum por entregas; mismo que se ofrecía como un novedoso material pedagógico: "muy útil a toda clases de personas y a propósito para la instrucción de los nińos que adquieran con mucha facilidad, por este medio, conocimientos en la historia, en la geografía, en las ciencias y en las artes. Algunos colegios de esta capital han adoptado el álbum fotográfico para instruir a los niños, y no hay duda que en este ramo de educación, lucirán mucho los alumnos en su examen público". ${ }^{73}$

El retrato de Ángela Peralta publicado en ese álbum, a principios del mes de abril de 1865 , fue celebrado por la prensa con este pequeño verso: "Elección soberbia es esa, /Cuéllar, y nada le falta, /A la Angelita Peralta, /Que hoy nos ofrece tu empresa". ${ }^{74} \mathrm{Su}$ imagen, más que una simple fotografía o un souvenir, era un medio para dar a conocer las últimas noticias de la soprano mexicana en el Viejo Continente. La nota biográfica informaba que: "Actualmente canta en Alejandría de Egipto, [...] ¡ Loor eterno á la joven artista que ha llevado

7I. "El álbum fotográfico", El Cronista de México, Ciudad de México, 28 de noviembre de $\mathrm{I} 865,2$.

72. El escritor José Tomás de Cuéllar fue además un fotógrafo aficionado, de cuya autoría se han localizado retratos en colecciones particulares.

73. "El álbum fotográfico", El Cronista de México.

74. "Álbum fotográfico", La Sombra, Ciudad de México, 2 de mayo de I865, 4. 
4. Anónimo, Ángela Peralta, ca. 1865, albúmina, $6.3 \times 10.2 \mathrm{~cm}$. Colección Museo del Estanquillo.

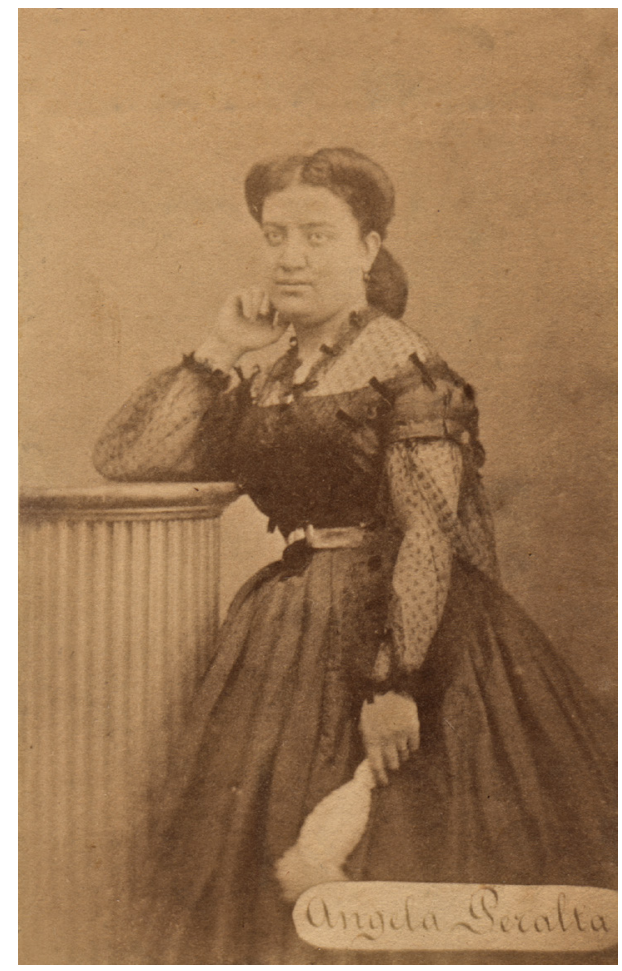

con gloria el nombre de México, en la tierra clásica del canto, y hasta el mismo pié de las seculares pirámides de los Toloméos!"75 También se incorporaron los últimos sucesos de la joven cantante en su semblanza, incluso cuando empezó a circular este álbum ya aparecía la noticia de su presentación del 29 de noviembre de 1864 en el Teatro Zizinia en Alejandría. Como en este caso, la fotografía en formato carte-de-visite se utilizó para divulgar la imagen e informar las noticias y novedades, antes de su regreso a su patria.

75. Esta información coincide con la que registra Agustín F. Cuenca en la biografía de la Peralta, ya que afirmó que la cantante actuó en Egipto el 29 de noviembre de I864, "inaugurando el Teatro Zizinia, interpretando de manera admirable Roberto il Diavolo", en Cuenca, Ángela Peralta de Castera, 29. 


\section{Las primeras fotografias en México}

Si en su momento la litografía había impulsado inicialmente la celebridad de las actrices mexicanas y extranjeras, llegando a su máxima expresión durante la década de $1840{ }^{76}$ ahora la fotografía habría de consolidar y expandir el culto a las divas de la escena, y continuar lo que la litografía había iniciado: por medio de retratos, crear un imaginario nacional, con un grupo de gobernantes, héroes, mitos y celebridades único y diferente al de otras naciones.

Hacia la década de I86o, el arte se vio popularizado por la fotografía en papel en el formato carte-de-visite; la pintura, la arquitectura, las vistas de paisajes, así como los retratos de escritores, políticos, actores y cantantes se vendían por cientos, por miles, ya que existía un mercado ávido de imágenes por conocer y poseer.

Como señala Gisèle Freund, el teatro se volvió más popular gracias a la fotografía, ${ }^{77}$ los retratistas comprendieron esa necesidad y ofrecieron ricas galerías de actores, cantantes y bailarinas, en el formato práctico de las carte-de-visite, como ocurrió también en México. ${ }^{78}$ En medio del auge del coleccionismo fotográfico, muchos de los álbumes mexicanos de la segunda mitad del siglo XIX atesoraron entre sus páginas la imagen de Ángela Peralta.

Después de su regreso a México a finales de 1865 , la joven cantante asistió al gabinete de Andrés Martínez en la capital del imperio; para ese momento, el establecimiento gozaba de un bien cimentado prestigio tras dedicarse "desde hace muchos años al arte de la fotografía”, según afirmaba una crónica publicitaria de su estudio. ${ }^{79}$ De la Peralta, existen por lo menos cuatro variantes de la misma sesión: en la primera, ella aparece parada cerca de una columna; en otra, cercana a un sillón casi de perfil; también aparece sentada, en actitud de lectura con un libro abierto; en un cuarto retrato, se la ve mirando hacia la cámara esbozando una sonrisa (figs. 5a-d); finalmente, existe un quinto retrato

76. Montserrat Galí Boadella, Historias del bello sexo. La introducción del romanticismo en México (Ciudad de México: Universidad Nacional Autónoma de México-Instituto de Investigaciones Estéticas), 319.

77. Gisèle Freund, La fotografía como documento social (Barcelona: Gustavo Gili, 1993), 58.

78. Hacia I867 el catálogo del estudio de Cruces y Campa ofrecía un total de 4I retratos dentro del grupo de personalidades de "Teatro", entre ellos, I8 eran de actrices y cantantes nacionales y extranjeras, véase el catálogo Fotografía artística de Cruces y Campa (México: s. e., ca. I867).

79. "La fotografía del Sr. Martínez", El Cronista de México, México, 4 de octubre de 1866, 3. 

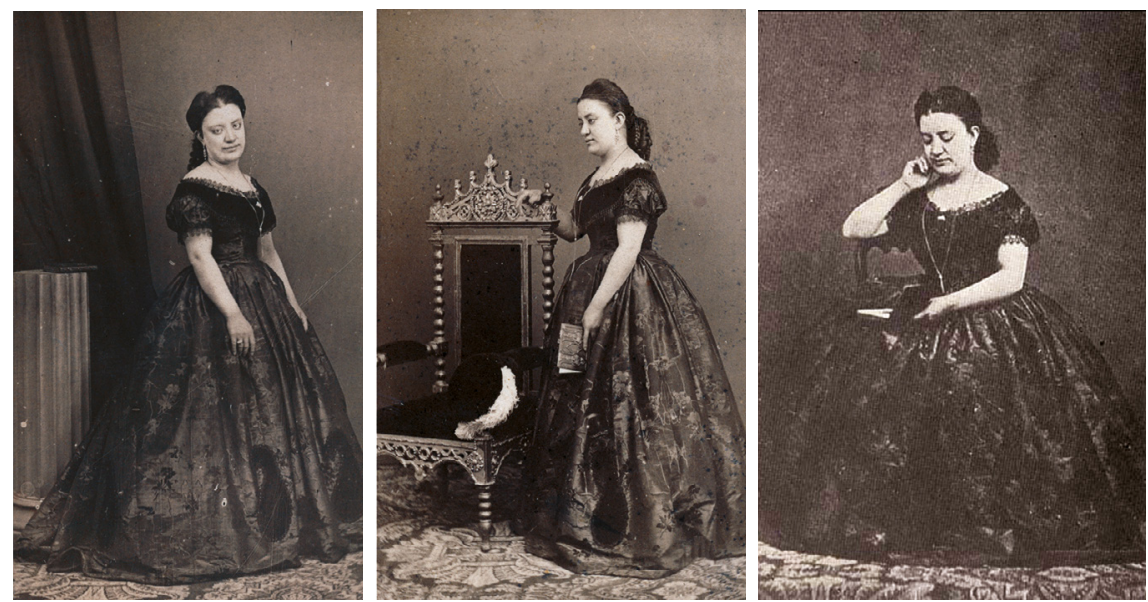

sa, b, c, d, e. Andrés Martínez, Ángela Peralta, $c a$. I866, albúminas, $6.3 \times 10.2$ $\mathrm{cm}$. Colección Museo del Estanquillo y Eduardo García Ramírez.
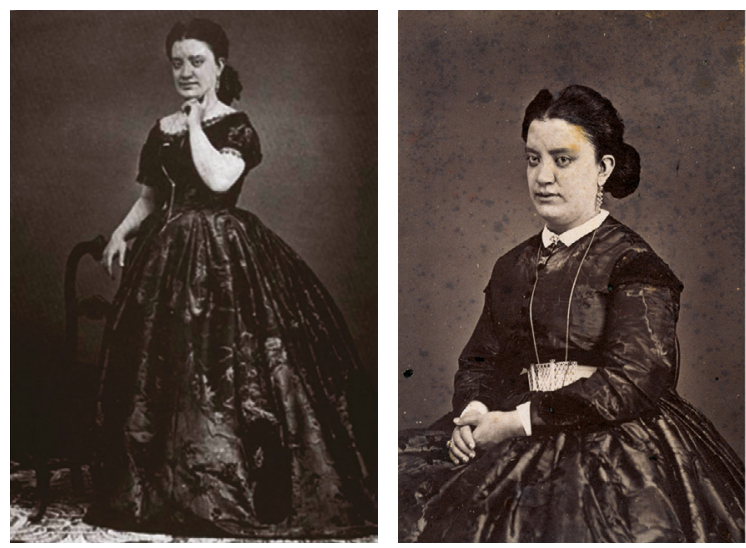

de Martínez, de medio cuerpo, posando sentada con las manos entrecruzadas, que pudiera haberse tomado en esa misma sesión, aunque con cambio de vestido y cabello recogido atrás (fig. 5e).

La popularidad y demanda de la imagen de la diva mexicana fueron determinantes para que se realizara tal cantidad de fotografías en una misma sesión, un hecho inusual en cualquier celebridad hasta entonces registrada. Andrés Martínez trató de sacar el mejor provecho de la Peralta, dirigió su pose haciéndole colocar la vista hacia abajo, o en la postura de tres cuartos de perfil, hacia la derecha y a la izquierda, para mejorar la imagen de la cantatriz, de cuyo 
aspecto físico comentó el príncipe Carl Khevenhüller que era "gorda hasta la deformidad" ${ }^{80}$ Rafael Heliodoro Valle la describió de tez "trigueña, tenía ojos ligeramente saltones como si padeciera de bocio y su cuerpo carecía de esbeltez". Por su parte, Artemio del Valle Arizpe, la definió como "achaparrada, gorda, de un moreno indígena, con ojos saltones de mirar estrábico, pero con una voz extraordinaria" ${ }^{81}$ Los fotógrafos sabían cómo dirigir a sus modelos con el propósito de aminorar u ocultar los defectos físicos.

A pesar de que en los periódicos de la época no se han localizado anuncios publicitarios de las imágenes realizadas por Andrés Martínez, la cantidad de copias de aquella sesión que aún se conservan en colecciones fotográficas, indica que se vendieron con gran éxito comercial.

En febrero de 1866 se tomaron otras fotografías a la cantante, como la del fotógrafo Salvador Murillo, a la sazón estudiante de pintura quien, en compañía de sus condiscípulos de la Academia de San Carlos, le realizó un retrato en su estudio - que imprimió en ese mismo momento-, además de ofrecerle a la joven cantante un concierto de cuerdas, entre brindis "liberales y entusiastas" ${ }^{82}$ El periódico La Orquesta, en su edición del I4 de febrero de i866, reseña que dicho retrato "salió perfectísimo, y las copias se distribuirán entre numerosos amigos de nuestra compatriota, que les ha ofrecido con su dedicatoria correspondiente". ${ }^{83}$ Sin lugar a dudas, la figura triunfadora de la Peralta representó para los estudiantes mexicanos un modelo de éxito, una especie de "heroína de la juventud".

\section{La Peralta en el gabinete de Manuel Rizo}

Durante la estancia de la Compañía de Ópera Biacchi en la ciudad de Puebla, que se presentó en el Teatro Principal entre febrero y marzo de 1866, Ángela Peralta se hizo retratar en el gabinete de Manuel Rizo, quien al menos le tomó tres notables fotografías. Para el fotógrafo que captara la imagen de esta

8o. Brigitte Hamann, Con Maximiliano en México. Del diario de principe Carl Khevenhüller, I864-1867 (Ciudad de México: Fondo de Cultura Económica, I989), I62.

8I. Artemio del Valle Arizpe, Por la calzada de Tlacopan (Ciudad de México: Lotería Nacional para la Beneficencia Pública, 1937), 305.

82. "Un retrato", La Orquesta, México, I4 de febrero de I866, 4. La fotografía de Salvador Murillo no ha sido localizada con el sello de su autoría.

83. "Un retrato", La Orquesta. 
6. Manuel Rizo, Ángela Peralta, I866, albúmina, $6.3 \times$ IO. cm.

Colección particular.

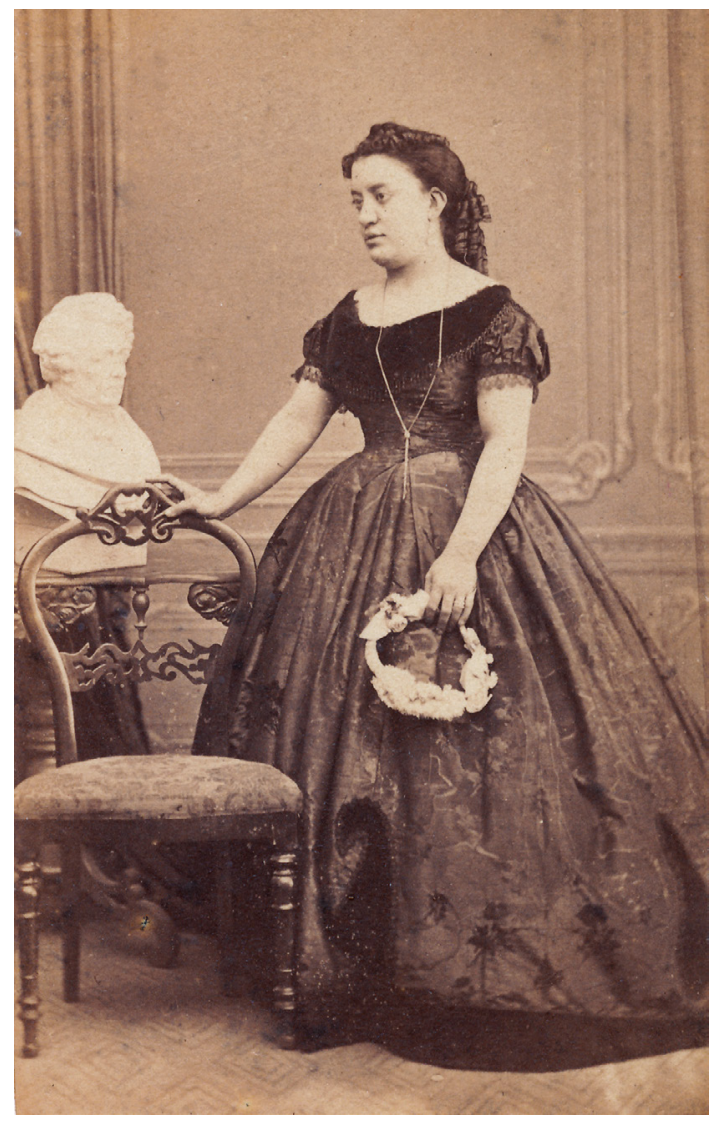

celebridad nacional era evidente que esto podía representar potencialmente un éxito de ventas, mientras que para la cantante era un importante medio de divulgación e impulsor de su popularidad.

En dos de los retratos se le captó de manera individual: en uno posó de pie, de cuerpo entero, sosteniendo una corona de flores con la mano izquierda, seguramente como una muestra de las muchas que recibió después de sus exitosísimas actuaciones, ${ }^{84}$ mientras que atrás de ella se aprecia el busto de Beethoven (fig. 6). Existe una segunda variante de esa pose en la que la cantante

84. Además de las coronas concedidas a su llegada, algunas crónicas refieren que le fueron otorgadas otras más a la soprano. "La señorita Peralta", La Sociedad, Ciudad de México, 28 de enero de I866, 3, y “Teatros y música”, La Sociedad, México, 9 de febrero de 1866, 2. 


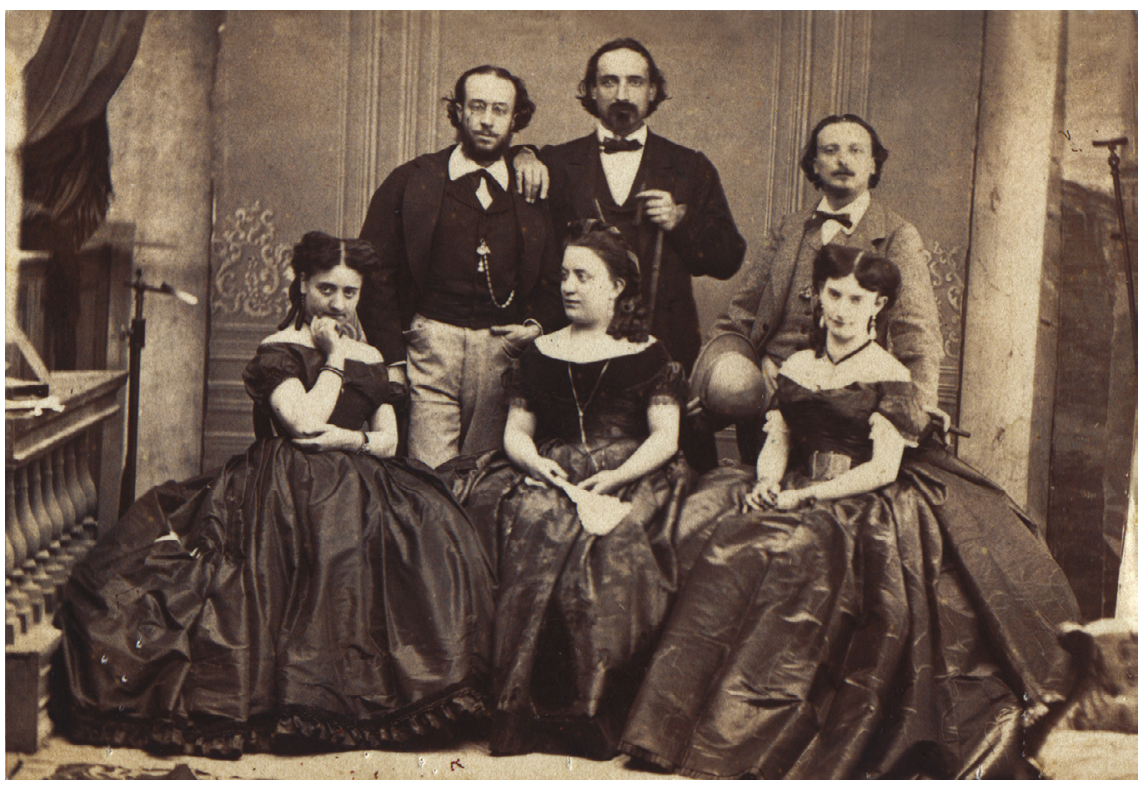

7. Manuel Rizo, Fanny Natali de Testa, Ángela Peralta, Isabel de Alba, José Tombessi, Mariano Padilla y Anníbale Biacchi, I866, albúmina, $6.3 \times 10.2 \mathrm{~cm}$. Colección particular.

también aparece de pie, pero de medio cuerpo, sosteniendo un abanico y en la parte superior de sus peinado estaba entrelazado con un listón. ${ }^{85}$

En la tercera fotografía, la soprano posó con el grupo de los principales cantantes de la compañía: está sentada, flanqueada a la derecha por Isabel de Alba y a la izquierda por Fanny Natali de Testa; de pie, se encuentran los cantantes José Tombessi y Mariano Padilla, mientras que de traje claro y sombrero en mano, se hizo retratar el mismo empresario Anníbale Biacchi (fig. 7). Lo interesante de este retrato es que, para la toma del grupo integrado por seis personajes, el fotógrafo no contaba con un telón de fondo lo suficientemente ancho, por lo que en los dos extremos de la fotografía captó detalles reveladores del estudio, como un cortinaje, un sujetacabezas y una balaustrada dispuestos en el lado izquierdo; en tanto que en el derecho se puede ver el despliegue de los telones y un sillón. En esta fotografía el descuido es total y los recursos y elementos del estudio quedan absolutamente al descubierto. A pesar de esto,

85. Colección Sinafo/Fototeca Nacional, núm. 452182. 
Rizo supo cómo sacar el mejor ángulo de la cantante y, en los tres retratos, la registró mirando hacia la derecha, en posición de tres cuartos, nunca viendo de frente hacia la cámara, postura que no la favorecía.

Estas imágenes de Ángela Peralta tuvieron una sorprendente demanda. La prensa publicó que el fotógrafo Manuel Rizo había reproducido, en tan sólo 24 horas, 400 fotografías de la cantante, retratada de manera individual y con la compañía de ópera del señor Biacchi. ${ }^{86}$ Estos datos revelan la enorme popularidad de la soprano también en otras ciudades fuera de la capital. La gira de la empresa incluyó otros departamentos del entonces Imperio Mexicano: Querétaro, Guanajuato, San Luis Potosí, Zacatecas, Aguascalientes y Jalisco.

En todas las ciudades la Peralta recibió enormes demostraciones de entusiasmo y admiración. Hecho que se puede constatar en el relato de Lucio Marmolejo, ${ }^{87}$ en una crónica remitida al periódico capitalino La Sociedad, sobre la función de beneficio para la soprano en el Teatro Principal en la ciudad de Guanajuato:

Comenzó con el bellísimo primer acto de "Traviata"; y tan luego como la Sra. Peralta se presentó en la escena, resonó un víctor unánime, acompañado de un aplauso universal, sostenido y prolongado: una espesa lluvia de flores y de versos llenó todo el ámbito del teatro: se hizo preciso interrumpir por un momento la representación; y a petición del público fue tocado, en honor de la artista mexicana el entusiasta Himno Nacional. ${ }^{88}$

\section{Ramilletes, coronas, palomas y versos}

Si para Fernando Benítez en su obra La Ciudad de México, los espectáculos teatrales decimonónicos fueron "un libro del pueblo, escuela de costumbres, con la misión civilizadora de censurar taras sociales y popularizar la historia"; ${ }^{89}$ la ópera representaba una oportunidad de conocer historias dramáticas

86. "Puebla. Establecimiento fotográfico", La Sociedad, Ciudad de México, 27 de marzo de I866, 3 .

87. En la nota publicada en el periódico La Sociedad, una errata adjudicó el artículo a Luis Marmolejo; pero el mismo texto coincide con el publicado en las Efemérides guanajuatenses del presbítero y cronista Lucio Marmolejo, verdadero autor de la crónica (Guanajuato: Imprenta del Colegio de Artes y Oficios, I883, vol. IV), 203.

88. "La señora Peralta en Guanajuato", La Sociedad, Ciudad de México, I2 de junio de 1866, 2.

89. Fernando Benítez, La Ciudad de México, vol. II (Ciudad de México: Salvat, 1982), 278. 
aderezadas con música que el público mexicano supo valorar. El género lírico fue un entretenimiento de largo arraigo, la investigadora Montserrat Galí Boadella seńala que para los mexicanos de mediados del siglo XIx la música fue un arte muy apreciado e intensamente practicado..$^{90}$ En particular la ópera permitía a los espectadores transportarse a regiones remotas, imaginar lugares exóticos, disfrutar las historias de diferentes reyes y personajes célebres, y conocer trágicos relatos de amor. El auditorio se entregaba con verdadera pasión al disfrute de sus intérpretes, a valorar su talento y a demostrarles, sin cortapisas, su vehemencia absoluta, para lo cual se valía de diferentes medios.

Innumerables crónicas de periódicos refieren cómo, al final de las interpretaciones de Ángela Peralta, el público le festejaba y agradecía su talento. Por ejemplo, en I866, al terminar Lucía de Lammermoor, el auditorio se volcó "victoreándola y arrojándole ramilletes, coronas, palomas y versos" ${ }^{91}$ al proscenio del teatro. La tradición de soltar palomas era un símbolo de gratitud y un premio a su actuación; los poemas tenían que escribirse y llevarse a la función ya impresos, para arrojarlos a los pies de los cantantes y del auditorio mismo; todos estos reconocimientos debían prepararse con antelación.

Un boceto anónimo al óleo, que pertenece al acervo del Museo Nacional de Historia, ${ }^{92}$ representa el final de la función de la ópera Aida, protagonizada años más tarde por Ángela Peralta. Este cuadro da una idea cabal de cómo eran aquellas manifestaciones populares de agradecimiento a la diva mexicana. En el proscenio del teatro se puede apreciar a la soprano en postura de ligera inclinación, dando las gracias al público y al director de la orquesta (fig. 8); al tiempo que el auditorio repleto le aplaude y la ovaciona, se ve caer una lluvia de sonetos impresos, que son arrojados desde los balcones del tercer piso, mientras que un sinfín de flores, ramilletes y coronas para la cantante, son lanzados al escenario. Cuatro palomas revolotean alrededor de ella ataviada como la princesa etíope, protagonista de la espectacular ópera compuesta por Verdi, e interpretada y producida por primera vez en México por la compañía de la Peralta en I877.

El I3 de septiembre de i866 en la ciudad de Guadalajara, la empresa de Annibale Biacchi, encabezada por Ángela Peralta, inauguró el Teatro de Alarcón (después llamado Teatro Degollado, en honor al militar y político Santos Degollado) con la ópera Lucía de Lammermoor. Aún sin terminar la

90. Galí, Historias del bello sexo, 48I.

91. "La señora Peralta”, El Noticioso, Ciudad de México, I6 de noviembre de I866, 2.

92. Agradezco a la investigadora Rosa Casanova la referencia de esta pieza. 


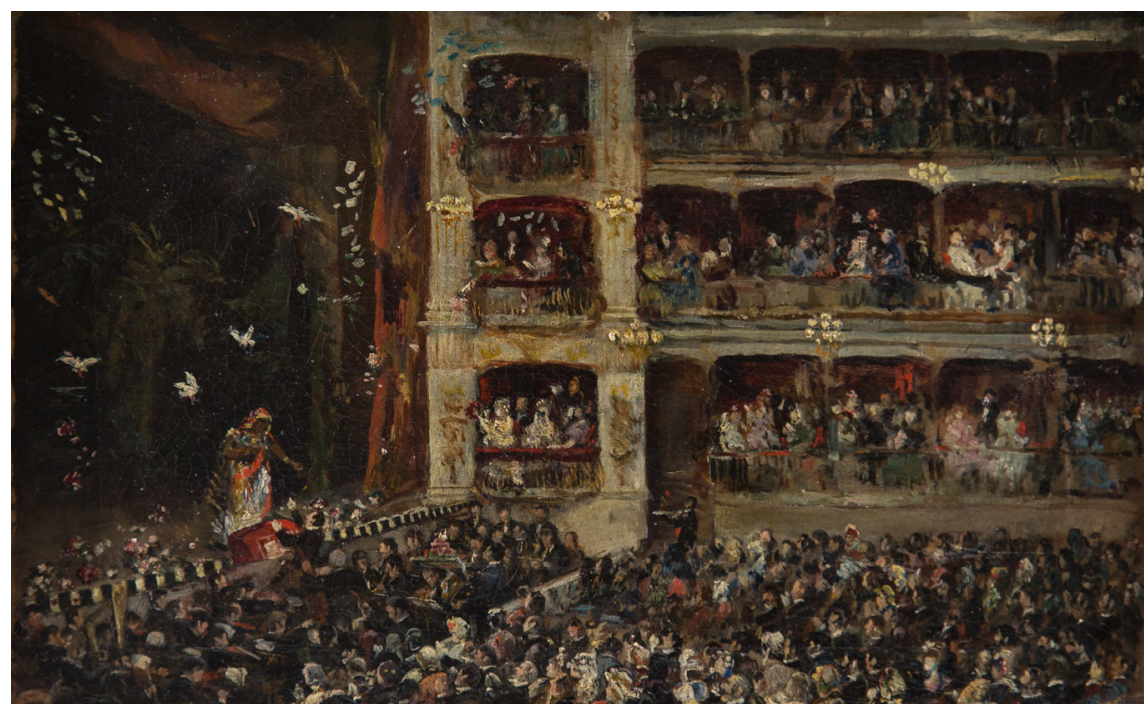

8. Anónimo, Ángela Peralta como Aída, ca. 1877 , óleo sobre tela, $26.8 \times 39.4 \mathrm{~cm}$. Colección Museo Nacional de Historia.

construcción del teatro, se decidió abrir el foro para que "el ruiseñor mexicano le otorgue bautismo y sea la distinguida Peralta la madrina de un edificio que formará una página de las glorias positivas de esta capital". ${ }^{93}$

La función transcurrió como otras de la gira con grandes demostraciones dirigidas a la soprano, entre "las positivas salvas de aplausos, los atronadores 'vivas' a México y a la cantante orgullo de la Patria, las dianas repetidas por la orquesta y la banda militar". ${ }^{94}$ En el segundo intermedio de la función, algunos cantantes y el arquitecto, el señor Jacobo Gálvez, tuvieron que salir ante el público a recibir aplausos por su interpretación y por la obra arquitectónica, mientras que "fueron leídas en su obsequio algunas composiciones en verso por los señores don Pantaleón Morett y don Celso Cevallos y circularon también entre el público, algunas en honor a la Peralta". ${ }^{95}$

Para el 2 de octubre se había planeado la función de beneficio para la soprano; en aquella ocasión, "al abrirse el escenario, apareció la Sra. Peralta, siéndole

93. Aurelio Hidalgo, El Teatro Degollado 1866-I896 (Guadalajara: Publicaciones del Gobierno del Estado, 1966), I7.

94. Hidalgo, El Teatro Degollado, 20.

95. Hidalgo, El Teatro Degollado, 21. 
luego presentado por el distinguido maestro Sr. Luna, un diploma a nombre de la sociedad jalisciense de 'Bellas Artes', igualmente que una banda formada por los colores nacionales". ${ }^{96}$ En esta "función de gracia" sus admiradores le arrojaron diversos poemas, ilustrados con su fotografía, utilizando una imagen realizada por el tapatío Octaviano de la Mora, que circuló con gran éxito comercial a partir de septiembre de 1866 (fig. 9).

De esta fecha memorable es el soneto firmado por "J. H.", e ilustrado con la fotografía realizada por De la Mora, que ejemplifica cómo eran ese tipo de impresos. ${ }^{97}$

Este ejemplar, ahora denominado del género de ephemera,${ }^{98}$ permite conocer el tipo de impresos ilustrados con la imagen fotográfica de la joven soprano (fig. Io). La parte superior del poema está rematado con el retrato de la Peralta, tomado por Octaviano de la Mora y decorado, manualmente, por un pequeño marco de orlas. ${ }^{99}$

\section{Otros retratos}

La oferta de las fotografías de famosos en formato carte-de-visite fue tan grande que, hacia 1867, el estudio de Cruces y Campa contaba para su venta con un gran catálogo de celebridades, que incluía en su listado las imágenes de gobernantes, políticos, altas autoridades eclesiásticas y militares, así como un variado grupo de artistas. El retrato de Ángela Peralta tuvo tal demanda que estaba en el listado de dicho catálogo, dentro del grupo de personalidades del "Teatro". ${ }^{100}$

96. "Beneficio de la Sra. Peralta", El Imperio. Periódico Oficial del Gobierno del Departamento de Jalisco, Guadalajara, 6 de octubre de i866, 4.

97. J. H., "A la señora Da. Angela Peralta, en la noche de su beneficio", Guadalajara, 2 de octubre de I866. Colección Fondo José Gutiérrez Casillas, S. J., de la Biblioteca Eusebio F. Kino, Instituto Libre de Filosofía y Ciencias, A. C. Agradezco la referencia de la maestra Teresa Matabuena.

98. El género de ephemera es definido por el investigador John E. Pemberton como el conjunto de "documentos que han sido producidos en relación con un acontecimiento determinado o un artículo de interés actual y que no pretenden a la actualidad de su mensaje". Rosario Ramos Pérez, Ephemera. La vida sobre papel (Madrid: Biblioteca Nacional, 2003), II.

99. Años más tarde, Ignacio Manuel Altamirano publicó una crónica sobre la costumbre de arrojar "chubascos de versos" a los intérpretes y sobre los poemas que dedicaron a Ángela Peralta en su gira en I87I, recordando que "en otros beneficios de hace dos o tres años, los versos arrojadizos no eran tan malos", en "Los poetas y la beneficiada”, El Federalista, Ciudad de México, Io de septiembre de I87I, I-2.

Ioo. Véase Fotografia Artística de Cruces y Campa. 
9. Octaviano de la Mora, Ángela Peralta, I866, albúmina, $6.3 \times 10.2 \mathrm{~cm}$. Colección Eduardo García Ramírez.

La fotografía debió hacerse en I866, antes de su regreso a Europa (fig. II). En la biografía de la cantante, que escribió Armando de Maria y Campos, se relata que ese retrato realizado por Cruces y Campa circuló profusamente en I867 y que se complementaba con una semblanza, impresa en el reverso de la cartulina.

Otros retratos importantes que circularon de Ángela Peralta se realizaron en el estudio de Valleto y Cía., en el que posó completamente de perfil, postura parecida a la fotografía editada por Julio Michaud (figs. I2a y b).

En la colección fotográfica reunida por el escritor Carlos Monsiváis, destaca un singular retrato anónimo, en el que Ángela aparece con su familia: su madre Josefa Castera está sentada en medio de la composición como el eje del matriarcado; a su alrededor se encuentran sus hijos Ángela, Manuel y Elena, además de otra nińa no identificada; la madre sostiene el brazo a su querida Ángela que, 
https://doi.org/10.22201/iie.18703062e.2020.117.2726

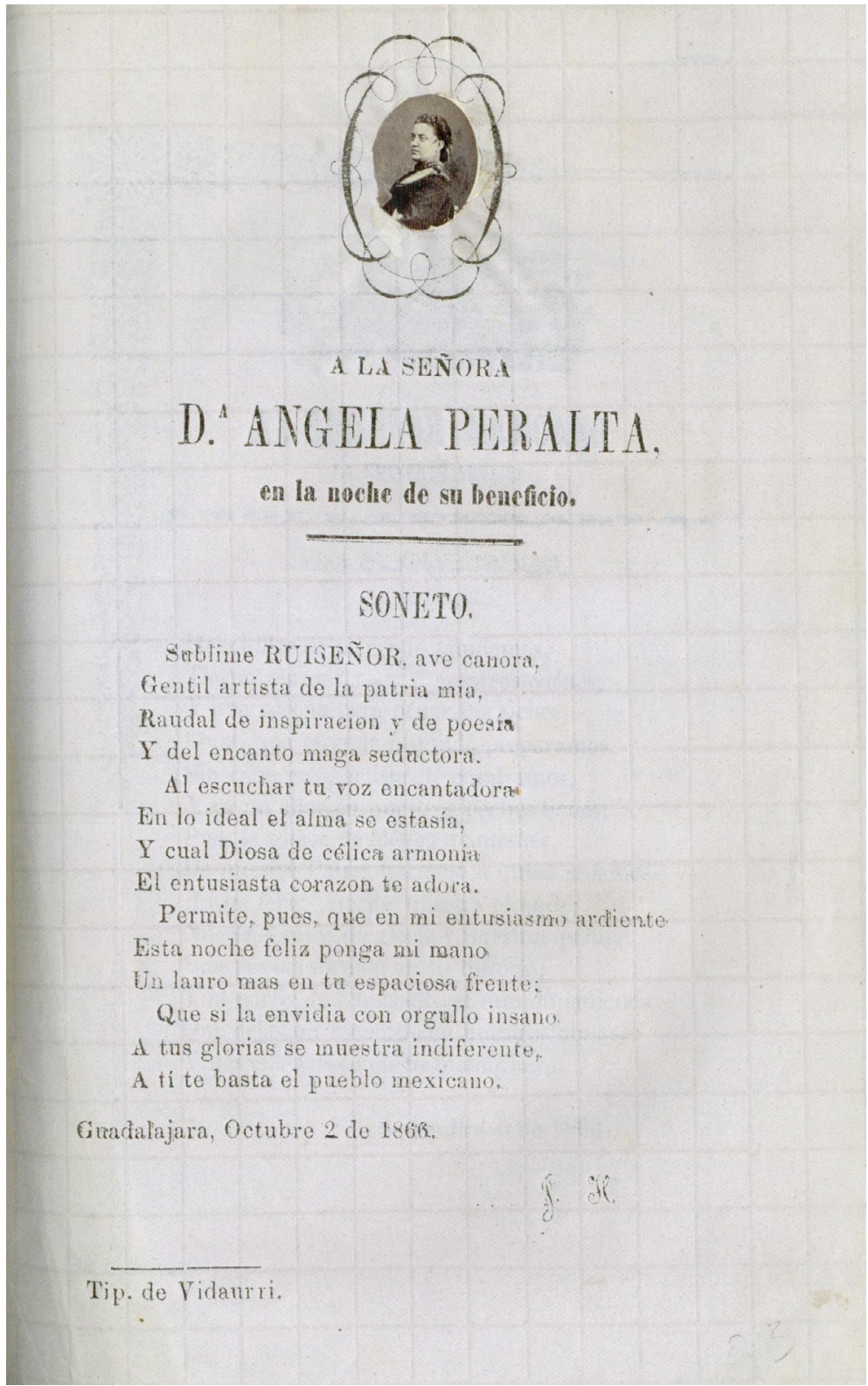

Io. J. H., A la señora Da. Ángela Peralta en la noche de su beneficio, I866, albúmina y papel, $6.3 \times 10.2 \mathrm{~cm}$. Instituto Libre de Filosofía y Ciencias, A. C., Biblioteca Eusebio F. Kino, Colección Fondo José Gutiérrez Casillas, S. J. 
II. Cruces y Campa, Ángela Peralta, I866, albúmina, $6.3 \times 10.2 \mathrm{~cm}$.

Colección Eduardo García Ramírez.

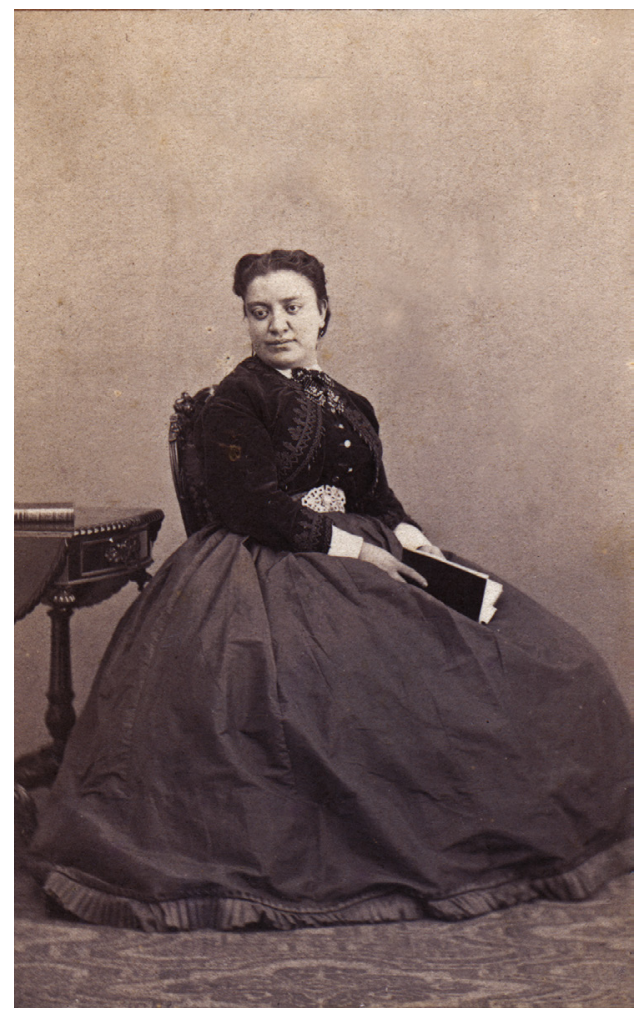

sentada en el piso, recarga su cuerpo y rostro sobre su regazo; en ausencia de la figura paterna, su abuela, atrás, enmarca la escena (fig. 13). Quizás, esta fotografía corresponda a su llegada, ya sin el padre que se había regresado a España con la otra familia que había formado. ${ }^{\text {Ior }}$ En abril de I866, Ángela Peralta se casó con su primo hermano Eugenio Castera (fig. I4); a falta de la presencia de su progenitor, que había fungido como su representante, ahora su esposo se encargó de sus futuros proyectos empresariales, entre ellos, montar su propia compañía de ópera.

A principios de enero de 1867, tras presentarse durante catorce meses en la capital y departamentos del Imperio Mexicano, Ángela Peralta partió a los Estados Unidos y a Europa a seguir con sus exitosas presentaciones; antes de su

IoI. Entrevista con la maestra Carmen Lugo Hubp, Ciudad de México, 9 de septiembre de 2016. 

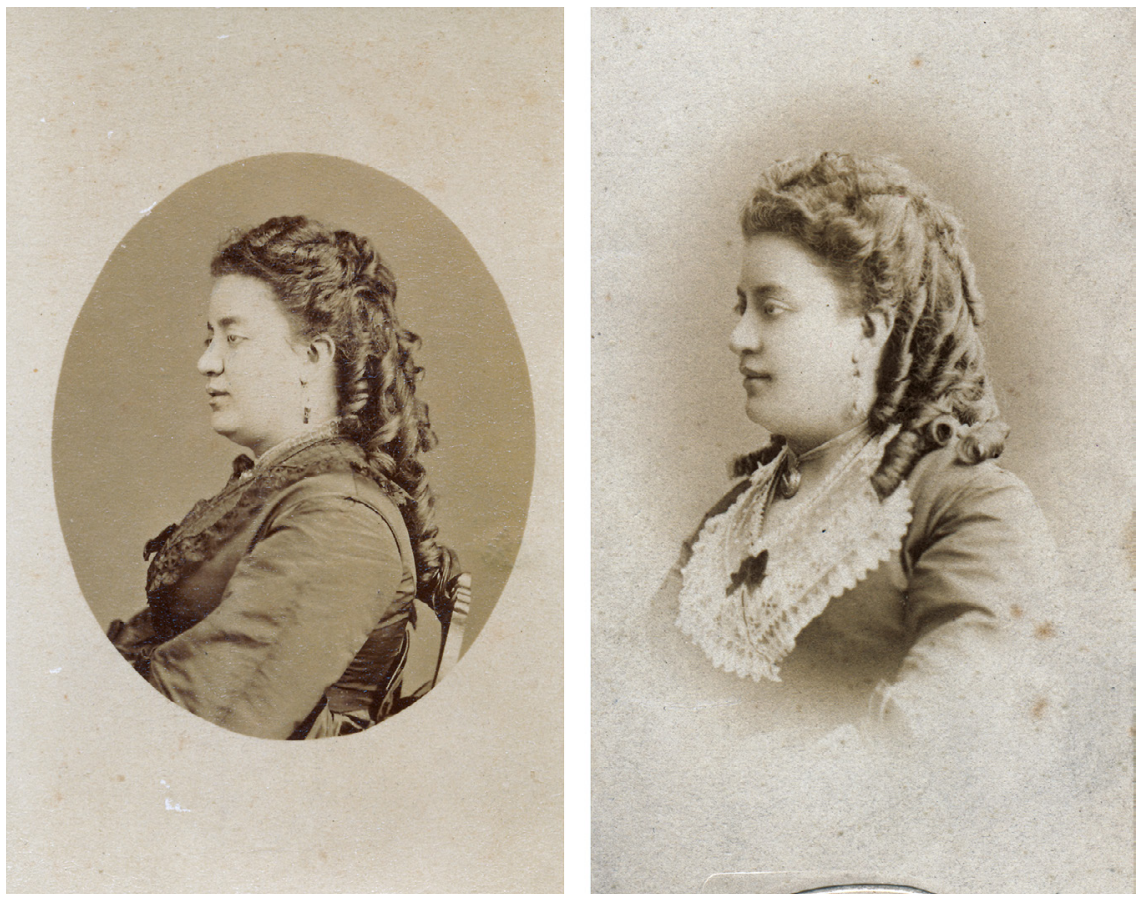

I2 a y b) Valleto y Cía. y Julio Michaud, Ángela Peralta, ca. 1866, albúminas, $6.3 \times 10.2 \mathrm{~cm}$. Colección particular y Colección Eduardo García Ramírez.

partida, publicó en la prensa una carta a sus compatriotas a razón de su última actuación en la Ciudad de México: "un corazón mexicano siempre es agradecido; y el mío que blasona de serlo en alto grado, conservará eternamente en él, y en una página de su álbum, una memoria grata de sus amigos y paisanos". ${ }^{102}$

\section{Réquiem por una vida}

Además de la fotografía editada por José Tomás de Cuéllar en el "El álbum fotográfico" donde se incluía una semblanza de la Peralta, en I87I circuló a la venta un pequeño cuaderno biográfico de cuatro páginas, impreso en papel de lujo, con un retrato de Ángela Peralta ejecutado por el litógrafo Arteaga y que,

IO2. "Al público", La Sociedad, Ciudad de México, 2I de diciembre de 1866, 3. 
I3. Anónimo, Ángela Peralta y familia, $c a$. I866, albúmina. $6.3 \times 10.2 \mathrm{~cm}$. Colección Museo del Estanquillo.

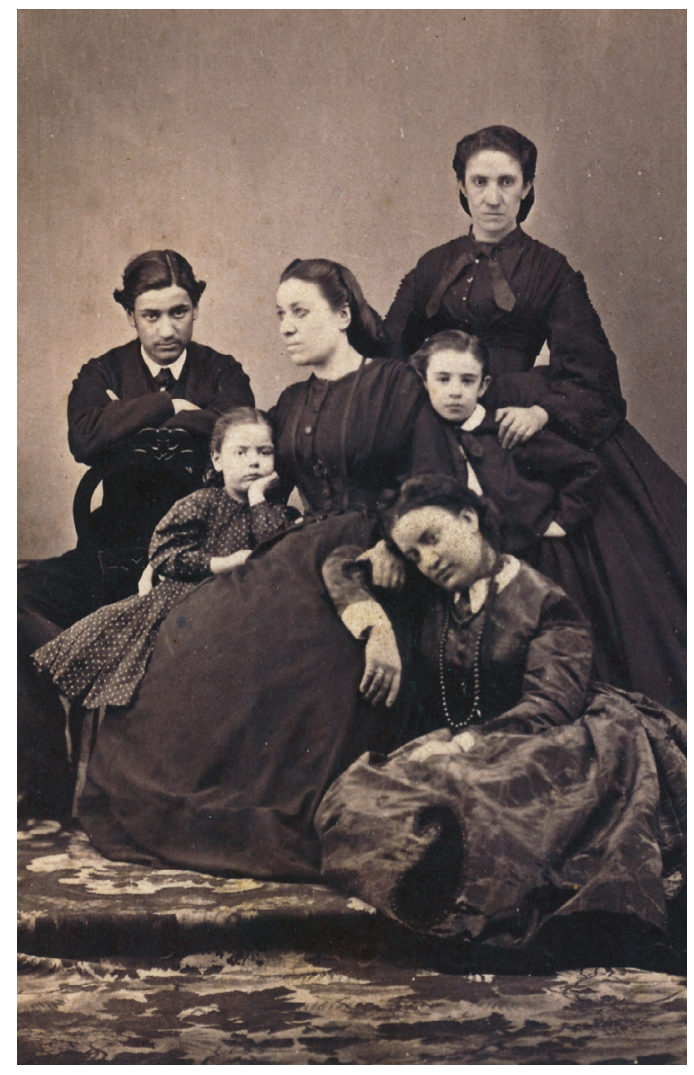

al parecer, se realizó "como un obsequio que varios artesanos hacen a la eminente artista”; el ejemplar se ofrecía al público a un real, según algunos periódicos capitalinos. ${ }^{103}$ Una tercera biografía, más amplia de cincuenta páginas, la escribió Agustín F. Cuenca en 1873, titulada Ángela Peralta de Castera. Rasgos biográficos, en la que al reverso de la portada se adhirió una litografía anónima de la diva mexicana. Para la realización de esta imagen, el litógrafo se basó

I03. "Obsequio a la Sra. Angela Peralta”, El Siglo Diez y Nueve, Ciudad de México, i7 de agosto de I87I, 3; "Obsequio a la Sra. Peralta", La Voz de México, Ciudad de México, I8 de agosto de I871, 3; "La Sra. Angela Peralta", El Ferrocarril, Ciudad de México, I9 de agosto de I87I, 3, y "Obsequio á la Sra. Peralta”, El Correo del Comercio, Ciudad de México, I9 de agosto de I87I, 2. El texto del impreso biográfico se reprodujo en el artículo "Obsequio a la Sra. Angela Peralta”, El Federalista, Ciudad de México, I9 de agosto de I87I, I-2. 


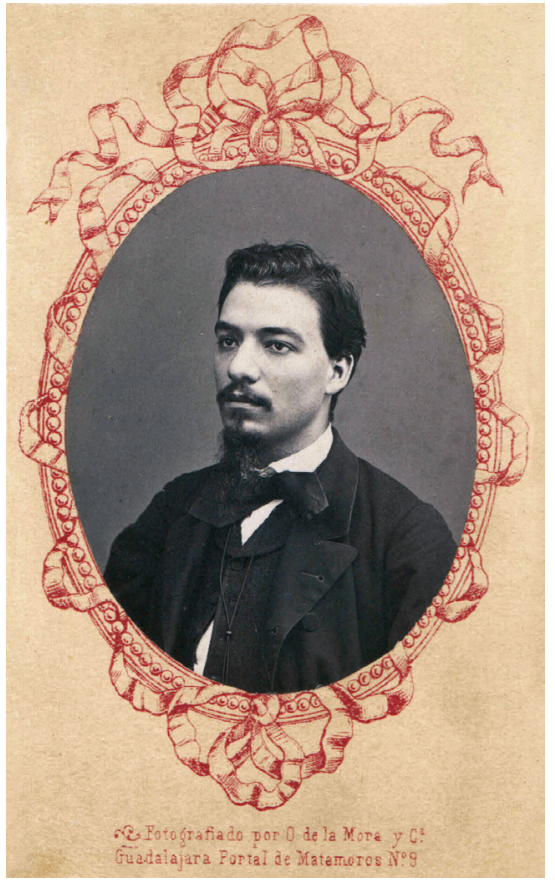

14. Octaviano de la Mora, Eugenio Castera, ca. 1866 , albúmina, $6.3 \times 10.2 \mathrm{~cm}$. Colección Eduardo García Ramírez.

en la fotografía de medio busto que le hiciera el retratista jalisciense Octaviano de la Mora. ${ }^{104}$ Es de destacar que, en menos de diez años ya circulaban tres impresos con notas biográficas, con sus respectivos retratos litografiados o fotográficos, para un público y un mercado deseoso por conocer su vida y de poseer su imagen: la joven soprano era una celebridad. La demanda de las fotografías de Ángela Peralta no sólo eran retratos de ella vestida con trajes de calle o de gala, también se adquirían aquellas en las que la diva se presentaba ataviada con las vestimentas de sus personajes.

$\mathrm{Al}$ igual que las protagonistas trágicas que interpretó en la ópera, Ángela Peralta debió de afrontar en sus últimos años de vida un destino adverso y difícil: la demencia de su marido Eugenio Castera, ${ }^{\text {1os }}$ la prematura muerte de éste

I04. Un detalle que lo confirma es el rizo que aparece en la sien de la cantante, en ambos retratos. El ejemplar consultado de esta biografía está resguardado en la Biblioteca del Instituto de Investigaciones José María Mora.

I05. Sobre la demencia de Eugenio Castera, véase "Sensible desgracia", El Pájaro Verde, Ciudad de México, 24 de abril de $1876,3$. 
en abril de $1875,{ }^{106}$ la cada vez menguada popularidad a mediados de la década de 1870 y el poco éxito de su empresa en los escenarios capitalinos; además de sobrellevar las penosas enfermedades de la diabetes y una miopía que la llevó casi hasta la ceguera. ${ }^{107}$ Aquella "estrella negra" con que la Peralta definió su vida, debió incluir algunos enemigos como el compositor Melesio Morales, quien dejó en las páginas de su diario las opiniones más duras y crueles contra la cantante, a la que definió de figura "casi asquerosa"; calificándola de mala hija, ciudadana, mujer, artista y de "ordinaria"; inclusive, sugiere sostener una relación de amasiato, pues aseguró con sarcasmo que "lleva muy buenas relaciones con $[\ldots]$ ", omitiendo el nombre del supuesto amante. ${ }^{108}$

La disminución de su popularidad, entre otros factores, pudo deberse a los rumores incisivos acerca de la relación sostenida con su apoderado y empresario teatral Julián Montiel y Duarte, antes de su viudez. Hernán Rosales, biógrafo de la cantante, relata así el declive de la Peralta: "como empezaron a circular los rumores de que entre la Peralta y su apoderado, el licenciado Montiel y Duarte, existía cierta intimidad, la sociedad, revestida de esa tesitura arcaica e inexorable para dictar sus fallos, le puso el 'sambenito' de la reprobación a la artista, y de allí que empezara para 'el ruiseñor mexicano' un periodo de torturante decadencia moral" ${ }^{109}$ La falta de interés hacia la Peralta, así como las rudas críticas corresponden hacia la última etapa de su vida, comprendida entre su tercero y último retorno de Europa en I876, y hasta su muerte en $1883 .{ }^{\text {IIO }}$

El público en la Ciudad de México que la había encumbrado, ahora le daba la espalda, iniciando una campaña en su contra para que nadie asistiera a sus funciones. La prensa conservadora hacía sarcasmos irritantes, lo que provocó una baja significativa de público en sus espectáculos; Ángela Peralta decidió no volver actuar en los escenarios capitalinos y emprender entonces una gira por la República mexicana. En una carta dirigida al periodista Enrique Chavarri "Juvenal" le confiesa con tristeza el momento amargo por el que está pasando:

I06. "Desgracia”, El Siglo Diez y Nueve, Ciudad de México, 25 de abril de 1876, 3.

I07. Isabel Haza Peralta, "Ángela Peralta", Revista Fem, Año 9, núm. 42, Ciudad de México (octubre-noviembre de 1985): 36. Agradezco el testimonio de la maestra Carmen Lugo Hubp, quien entrevistó a la sobrina-nieta de la cantante, la señorita Isabel Haza Peralta en 1985.

I08. Melesio Morales, Mi libro verde, introd. Karl Bellinghausen (Ciudad de México: Consejo Nacional para la Cultura y las Artes, 1999), 98.

ı09. Rosales, Amado Nervo, la Peralta y Rosas, iıo.

IIo. Bivián, "El canto del ruiseñor", 375. 
"Los amigos a la hora de los triunfos, en el estrépito de los aplausos y el resplandor de la gloria son infinitos, a la hora de la desgracia son contados." Según uno de sus biógrafos, fue en la ciudad de León, Guanajuato, donde Ángela Peralta se tomó la que probablemente sería su última fotografía:

Al llegar a la casa de las diligencias, la manifestación hizo alto para oír la palabra del licenciado Juan Antonio Valdivia, quién tendría que saludarla a nombre del pueblo leonés. El fotógrafo José Pacheco tomó al día siguiente una fotografía de Ángela Peralta, que fue la última de ella y que conserva en la actualidad el seńor [Nicolás] Rangel.

La artista se retrató con una cruz de brillantes en el pecho, que le había obsequiado el zar de Rusia, y un ramo de margaritas de diamantes en el peinado, recuerdo de Leopoldo II de Bélgica. Ambas cosas las conservaba como vestigio único de su grandeza. ${ }^{\mathrm{II}}$

$\mathrm{Al}$ encontrarse en aquella ciudad, le relata a su amigo Ignacio Manuel Altamirano los males que a ella y a su apoderado les aquejaban: "Enfermo Montiel y en ese estado yo no tengo facultad ni para pensar, y sufro tanto, que a veces me ha parecido que de un momento a otro, me muero de dolor." ${ }^{\text {I3 }}$ Ángela retomó la gira de sus actuaciones y después de presentarse exitosamente en La Paz, Baja California, se dirigió al puerto de Mazatlán, en donde contrajo la fiebre amarilla y falleció en I883, a los 38 ańos de edad.

Muchas fotografías de la cantante quedaron guardadas en los álbumes de las familias mexicanas de la segunda mitad del siglo xIx; otras quizá, las debieron haber retirado ante los rumores de aquella relación con su apoderado, que la moral de la sociedad mexicana de la época reprobó.

La trascendencia de Ángela Peralta en la historia de la ópera en México y en el mundo, radicó en su potente voz. Al recordarla, su compañera y amiga Fanny Natali de Testa afirmó que poseía "una voz de soprano sfogato, de

III. Carta de Ángela Peralta de Castera a Enrique Chavarri, Ciudad de México, I de enero de I877, vols. 32-36, Colección de autógrafos "Arquitecto Agustín Basave", Biblioteca Cervantina, Tecnológico de Monterrey.

II2. Rosales, Amado Nervo, la Peralta y Rosas, I25-I26. Según relata Rosales, Nicolás Rangel fue un historiador que trabajó en el Archivo General de la Nación, además de ser cronista y promotor de la vida de Ángela Peralta.

II3. Archivo Histórico de la Secretaría de Relaciones Exteriores, Correspondencia particular de Ignacio Manuel Altamirano I86I-I889, vol. I, Carta de Ángela Peralta de Castera a Ignacio Manuel Altamirano, León, Guanajuato, I9 de agosto de 1882. 
grande extensión y de un metal delicioso; una voz en que se unían los sonidos argentinos de las sopranos ligeras y las notas aterciopeladas de las sopranos dramáticas". ${ }^{114}$ Jamás conoceremos el sonido de aquellas vocalizaciones, escalas y gorjeos de su cantar ni cómo fueron los trinos y cadencias que emitía en sus interpretaciones. Lo que nos queda de ella como testimonio es un conjunto de fotografías que nos permiten conocer a una dama atípica y valiente, que forjó su propia empresa operística, además de desarrollar en paralelo una discreta producción como compositora de piezas para piano. Su imagen quedó en aquellos primeros álbumes que evocan a la primera celebridad mexicana conocida y reconocida por medio de sus retratos fotográficos.

Agustín F. Cuenca, en su biografía de la soprano, propuso a sus lectores connacionales: "felicitémonos [...] porque nuestra patria es la de Ángela Peralta" y acotó: "nosotros [...] sonreímos por el gozo de la República al abrigar bajo el palio de su orgullo a una reina del arte". ${ }^{116}$ El relato de Cuenca y los de otros biógrafos de la Peralta fueron construyendo ese halo mítico de la cantante.

La figura de la soprano se constituyó en un momento de tensión y disputa entre dos grupos irreconciliables que la utilizaron en sus respectivos proyectos de nación: los imperialistas la regresaron a su patria como símbolo de orgullo y prestigio, pero ella trascendió ese primer estigma y fue reconocida como la imagen o la encarnación de la Patria por parte de los republicanos. La figura nacional ya no era la representación de un ángel, o una doncella nativa, vestida de túnica de corte neoclásico, coronada con plumas y rodeada de símbolos nacionales. Ahora, la Patria era una mujer moderna, vestida de crinolina, laica y de su época. En la construcción de ese ideal fue notable la participación de ciudadanos, intelectuales, estudiantes y público de la ópera, quienes cifraron en la cantante la figura de la República liberal.

Ángela Peralta rompió muchos de los esquemas impuestos a la mujer mexicana del siglo XIX; su presencia, precedida de éxito según lo consignó la prensa mexicana tanto de talante conservador como liberal, exaltó los ánimos nacionalistas durante los años aciagos del imperio. Es a ella a quien convierten en el emblema de la esperanza republicana y lo que en ella proyectaron, mediante el discurso liberal. \$

II4. Titania (Fanny Natali de Testa), "Ángela Peralta", El álbum de la mujer, Ciudad de México, 30 de septiembre de I883, 58.

II5. Cuenca, Ángela Peralta de Castera, 6.

II6. Cuenca, Ángela Peralta de Castera, 8. 